\title{
Venom-Derived Neurotoxins Targeting Nicotinic Acetylcholine Receptors
}

\author{
Ayaulym Bekbossynova, Albina Zharylgap and Olena Filchakova * \\ Biology Department, School of Sciences and Humanities, Nazarbayev University, \\ Kabanbay Batyr Ave., 53, Nur-Sultan 010000, Kazakhstan; ayaulym.bekbossynova@nu.edu.kz (A.B.); \\ albina.zharylgap@nu.edu.kz (A.Z.) \\ * Correspondence: olena.filchakova@nu.edu.kz
}

check for updates

Citation: Bekbossynova, A.; Zharylgap, A.; Filchakova, O. Venom-Derived Neurotoxins Targeting Nicotinic Acetylcholine Receptors. Molecules 2021, 26, 3373 https://doi.org/10.3390/ molecules 26113373

Academic Editor: Clelia Dallanoce

Received: 30 March 2021

Accepted: 7 May 2021

Published: 3 June 2021

Publisher's Note: MDPI stays neutral with regard to jurisdictional claims in published maps and institutional affiliations.

Copyright: (c) 2021 by the authors. Licensee MDPI, Basel, Switzerland. This article is an open access article distributed under the terms and conditions of the Creative Commons Attribution (CC BY) license (https:// creativecommons.org/licenses/by/ $4.0 /)$.

\begin{abstract}
Acetylcholine was the first neurotransmitter described. The receptors targeted by acetylcholine are found within organisms spanning different phyla and position themselves as very attractive targets for predation, as well as for defense. Venoms of snakes within the Elapidae family, as well as those of marine snails within the Conus genus, are particularly rich in proteins and peptides that target nicotinic acetylcholine receptors (nAChRs). Such compounds are invaluable tools for research seeking to understand the structure and function of the cholinergic system. Proteins and peptides of venomous origin targeting $\mathrm{nAChR}$ demonstrate high affinity and good selectivity. This review aims at providing an overview of the toxins targeting $\mathrm{nAChRs}$ found within venoms of different animals, as well as their activities and the structural determinants important for receptor binding.
\end{abstract}

Keywords: $\mathrm{nAChR}$; $\alpha$-conotoxins; three-finger $\alpha$-neurotoxins

\section{Introduction}

\subsection{Structural Features of Nicotinic AChRs for Ligand Interaction}

Nicotinic acetylcholine receptors (nAChRs) are channel-coupled membrane receptors activated endogenously by acetylcholine $(\mathrm{ACh})$ [1]. Together with ionotropic GABA (gamma-aminobutiric acid), glycine, 5-HT3 (5-hydroxytryptamine), and zinc activated ion channels, they belong to a cys-loop superfamily of ligand-gated ion channels [2]. The receptors are characterized by radial symmetry and have pentameric organization, with five subunits arranged radially around a central ion-conducting pore. The ACh binds at the interface between adjacent subunits. There are 17 subunits described in vertebrates: $\alpha 1$ to $\alpha 10, \beta 1$ to $\beta 4, \gamma, \delta$, and $\varepsilon$. The $\alpha 8$ subunit is found in the avian genome [3] and is not present in the human genome. The difference between $\alpha$ and $\beta$ subunits lies within the structure of the ligand-binding site-an $\alpha$-like subunit is considered to contribute to the ligand-binding site with a principal (+) subunit interface, which includes loops $A, B$, and C, whereas a $\beta$-like subunit is considered a complementary $(-)$, contributing with loops $\mathrm{D}, \mathrm{E}$, and $\mathrm{F}$ to the ligand-binding interface. The $\alpha 2, \alpha 3, \alpha 4$, and $\alpha 6$ subunits, through their association with $\beta 2$ or $\beta 4$ subunits, can form heteromeric receptors, with different stoichiometries of $2(\alpha) 3(\beta)$ or $3(\alpha) 2(\beta)$. More than one type of $\alpha$ and/or $\beta$ subunits within a receptor could increase receptor diversity. $\alpha 5$ and $\beta 3$ subunits are considered auxiliary subunits, not contributing to the ACh binding site but influencing properties of the receptor [4,5]. $\alpha 7$ and $\alpha 9$ subunits can assemble into a homomeric receptor. However, association with other subunits is also possible. For example, $\alpha 7$ can associate with $\beta 2$ [6], while $\alpha 9$ associates with the $\alpha 10$ subunit [7]. $\alpha 1, \beta 1, \delta, \varepsilon$, and $\gamma$ are subunits within muscle-type of $n A C h R$, with $\varepsilon$ subunits present in adult receptor type, while $\gamma$ subunit present in fetal receptor.

Each subunit contains an N-terminal extracellular domain (ECD) which contributes to the formation of an orthosteric ligand-binding site, a transmembrane domain containing four $\alpha$-helices, out of which a second helix contributes to channel pore formation, and an intracellular domain (Figure 1). The orthosteric ligand-binding site is formed at the junction 
between two neighboring subunits, where loops $A, B$, and $C$, from principal subunits and loops D, E, and F, coalesce and form a hydrophobic cage from aromatic residues that provides a space for $\mathrm{ACh}$ binding. The aromatic residues protruding to the ligand-binding site are rather conserved; within the muscle $\alpha 1$ subunit, they include Tyr 93 from loop A, Trp 149 from loop B, and Tyr 190 and Tyr 198 from loop C. These aromatic residues within the principal subunit are assisted by aromatic residues of a complementary subunit, such as Trp 57 of the $\gamma$ subunit [8]. The conserved aromatic residues interact with ligands via cation $\pi$ interaction.

A

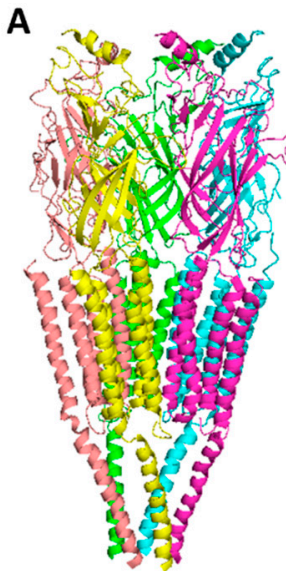

Side view

B

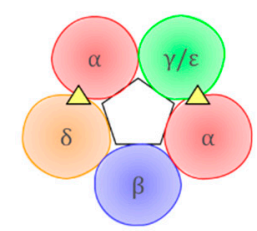

Muscle

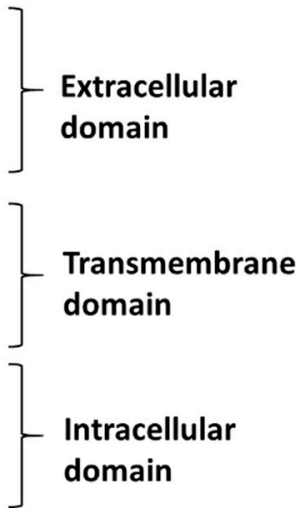

domain

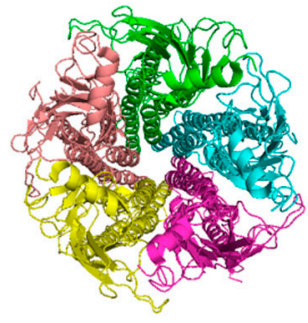

Top view

heteromeric

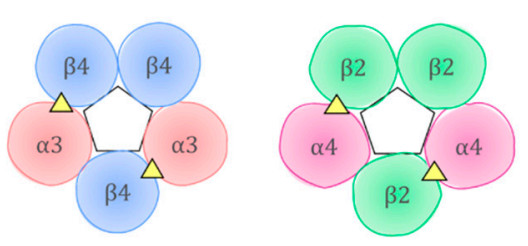

Neuronal

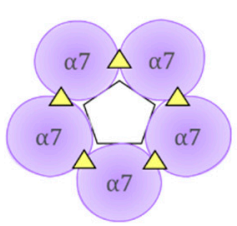

homomeric

Figure 1. Representation of the structure of nAChR: (A) Cartoon structure of a muscle-like nAChR with pentameric organization shown through side and top views. Ligand-binding extracellular domain, pore-forming transmembrane domain, and an intracellular domain are shown. PDB accession number is 2BG9. (B) Cartoon representation of assembled muscle and neuronal nAChR subtypes. The pentameric organization of the receptor is shown. The triangles represent the subunit interfaces where endogenous ligands and competitive antagonists bind. In the muscle receptor, a $\gamma$-subunit is present in fetal form, while an adult receptor contains the $\varepsilon$-subunit. Two ligand-binding sites include $\alpha / \delta$ and $\alpha / \varepsilon$ or $\alpha / \gamma$ interfaces, where the $\alpha$ subunit is considered principal, contributing with loops $\mathrm{A}, \mathrm{B}$, and $\mathrm{C}$, whereas $\delta, \varepsilon$, and $\gamma$ are complimentary subunits, contributing with loops $\mathrm{D}$, $\mathrm{E}$, and $\mathrm{F}$ to the ligand-binding interface.

The receptor structure was studied at an atomic level. The quest for receptor structure determination was facilitated through studies on acetylcholine-binding protein (AChBP), a soluble multimeric protein secreted by snail glial cells which buffers ACh concentration [9]. 


\subsection{Importance of Nicotinic Acetylcholine Receptors in Physiology and Pathology}

Acetylcholine is a widely distributed excitatory neurotransmitter. Within the human body, it is present in both branches of the autonomic nervous system: within the parasympathetic system in pre- and postganglionic cells, and within the sympathetic system in preganglionic cells. It is also a neurotransmitter at the periphery within the neuromuscular junction. nAChRs are widely distributed within the central nervous system (CNS) and peripheral nervous system, as well as outside the nervous system. The nucleus basalis of Meynert consists of cholinergic neurons widely projecting into different brain locations [10]. The most prevalent receptor subtype within the brain is the $\alpha 4 \beta 2$-containing receptor, the upregulation of which is observed following chronic nicotine consumption [11]. Existing in two stoichiometric forms $\left((\alpha 4)_{2}(\beta 2)_{3}\right.$ and $\left.(\alpha 4)_{3}(\beta 2)_{2}\right), \alpha 4 \beta 2$-containing receptors can vary in their sensitivities to $\mathrm{ACh}$ [12]. nAChRs play an important role in the regulation of neurotransmitter release within central synapses, in activating the muscle at periphery. They play critical role within reward pathways, in particular, within nigrostriatal dopaminergic circuitry [13]. Recent discoveries have expanded the potential role of the receptors, and their significance was shown for pain signal transmission, particularly for $\alpha 9 \alpha 10 \mathrm{nAChR}$ [14-16]. The receptors play a key role in an anti-inflammatory pathway, with an involvement of immune cells and vagal nerve activation [17].

Disfunction in nAChRs within neuromuscular junctions can lead to myasthenic syndrome. Within the CNS, abnormal functioning of the receptors can manifest itself as Alzheimer's disease, schizophrenia, depression, and Parkinson's disease [18]. Outside the CNS, improper functionality of the receptors can lead to skin disorders such as pemphigus vulgaris and cancer.

Thus, knowledge about the functionality of the receptors is of paramount importance. Ligands targeting the receptors can help decipher physiological mechanisms, as well as prevent pathological processes where receptors are involved $[19,20]$. Natural products and, in particular, venoms of venomous animals, such as snails, snakes, spiders, and scorpions, contain biologically active compounds targeting nAChRs; thus, they are actively and thoroughly investigated [21].

\section{Snail Venoms as a Source of Toxins Acting on Acetylcholine Receptors}

Predatory snails within the Conus genus produce peptides-conotoxins that target different ion channels [22]. Conotoxins differ in their number of disulfide bonds. The peptides with a general structure CC-Xm-C-Xn-C, where $C$ represent cysteines, $\mathrm{Xm}$ and $\mathrm{X} n-$ variable number of residues between cysteines-constitute the family of $\alpha$-conotoxins $(\alpha$-Ctx). $\alpha$-Conotoxins are competitive antagonists of $n A C h R s ~[23,24]$. The different number of residues within two loops contributes to the division of the $\alpha$-conotoxins into several subgroups $(3 / 5,4 / 3,4 / 4,4 / 5,4 / 6$, and $4 / 7)$. Structurally, $\alpha$-conotoxins have very rigid three-dimensional structure due to the restraints imposed by disulfide bonds. Many $\alpha$ conotoxins have a conserved proline in loop 1 between Cys 1-Cys 3, which contributes to structural stability. $\alpha$-conotoxins with four residues in loop 1 form a small $3_{10} \alpha$-helical region. Functionally, $\alpha$-conotoxins could be divided into two groups: those targeting muscle-type nAChRs ( $\alpha 3 / 5$ conotoxins) and those targeting neuronal nAChRs ( $\alpha 4 / 3$, $\alpha 4 / 4, \alpha 4 / 5, \alpha 4 / 6$ and $\alpha 4 / 7$ conotoxins).

\section{1. $\alpha 3 / 5$ Conotoxins}

$\alpha 3 / 5$ conotoxins predominantly target muscle subtypes of nAChRs [25]. The two most well-studied of them include MI and GI conotoxins. $\alpha$-Conotoxins MI, GI, and SIA have been shown to exhibit $>10,000$-fold selectivity for $\alpha / \delta$ over the $\alpha / \gamma$ site in mammalian receptors (Table 1). However, the reverse pattern is observed in Torpedo receptors. Conserved Pro 6 and Tyr 12 residues are critical for hydrophobic interaction between the $\delta$ subunit and MI [26].

Ac1.1a and Ac1.1b are almost identical $\alpha 3 / 5$ conotoxins differing in only one residue at position 14 [27] (Figure 2). They exhibit selectivity towards $\alpha / \delta$ over $\alpha / \gamma$ site. The first 
three residues before the Cys 4 have been shown to lack an effect on binding the target.

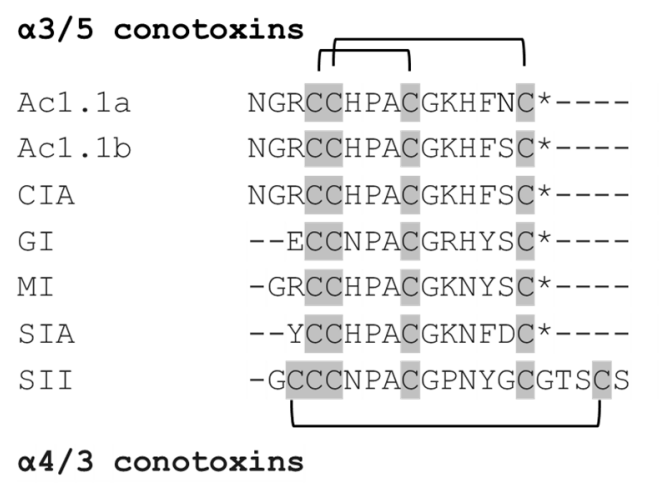

\begin{tabular}{lll} 
& \multicolumn{1}{c}{} \\
ImI & GCCSDPRCAWRC* & 12 \\
ImII & ACCSDRRCRWRC* & 12 \\
RgIA & GCCSDPRCRYRCR & 13
\end{tabular}

$\alpha 4 / 4$ conotoxins

\begin{tabular}{lll} 
& \multicolumn{1}{c|}{} \\
BUIA & --- GCCSTPPCAVLYC* & 1 \\
EIIA & QTPGCCWNPACVKNRC* & 16 \\
PIB & ZSOGCCWNPACVKNRC* & 16
\end{tabular}

$\alpha 4 / 6$ conotoxins

\begin{tabular}{|c|c|c|}
\hline AuIB & -GCCSYPPCEATNPDC* & 15 \\
\hline ViIA & RDCCSNPPCAHNNPDC* & 16 \\
\hline $\operatorname{VnIB}$ & GGCCSHPVCYTKNPNCG* & 17 \\
\hline TXID & -GCCSHPVCSAMSPIC ${ }^{\star}$ & 15 \\
\hline
\end{tabular}

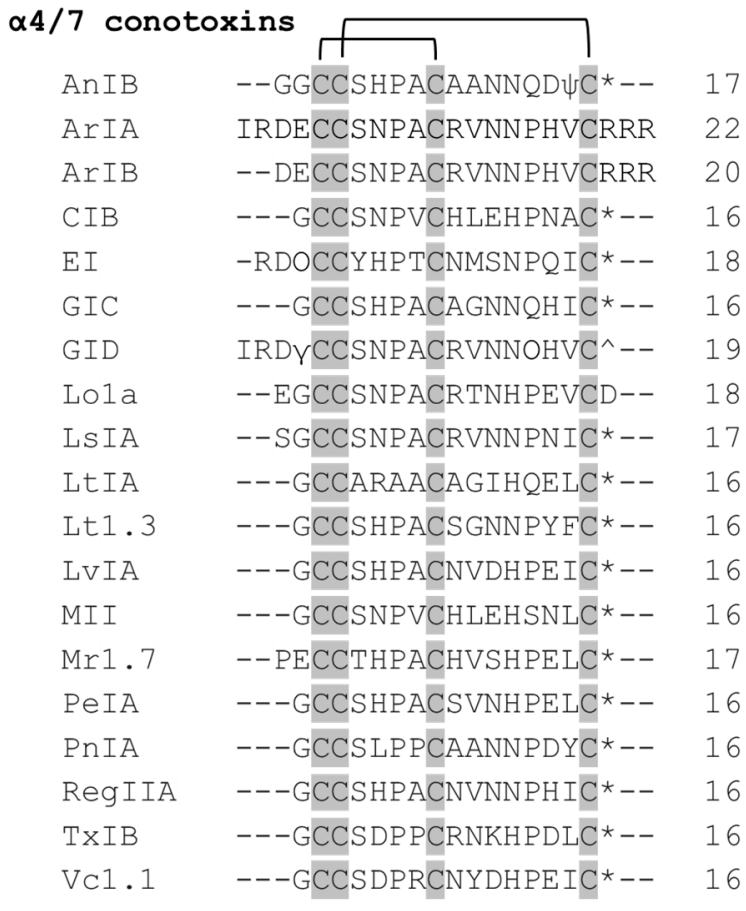

Figure 2. Sequence alignment of the $\alpha$-conotoxins listed in a Table 1 . The $\alpha$-conotoxins with $3 / 5,4 / 4,4 / 6$, and $4 / 7$ spacing. The cysteines residues are shaded in gray and intrachain disulfide bonds are shown. The number of residues in each toxin is given to the right. * $\mathrm{C}$-terminal carboxamide, ^ $\mathrm{C}$-terminal carboxylate, $\psi$ - sulfated tyrosine, $\mathrm{O}$-hydroxyproline, Z-pyroglutamate.

$\alpha$-Conotoxin GI blocks muscle-type nAChRs, with selectivity for the $\alpha / \delta$ site in mouse muscle receptors [28], and the $\alpha / \gamma$ site in Torpedo californica electric organ receptors [29]. Pro 5, Gly 8, Arg 9, and Tyr 11 are critical residues for GI to target mouse $\alpha 1 \beta 1 \delta \varepsilon$ nAChRs. [E1A] GI mutant demonstrated a three-fold increase in potency in mouse $\alpha 1 \beta 1 \delta \varepsilon$ and a decreased potency in rat neuronal $\alpha 9 \alpha 10 \mathrm{nAChR}$, compared to wildtype GI [30].

NMR structures for both CIA and CIB alpha-conotoxins derived from Conus catus have been studied. $\alpha$-Conotoxin CIA caused muscle paralysis in fish when tested in vivo [31], while $4 / 7 \alpha$-Conotoxin CIB blocked neuronal type nAChRs.

Overall, there are two conserved regions (residues 2 and 3 in the first cysteine loop, as well as residues 1,2 , and 4 in the second cysteine loop) inherent to $\alpha 3 / 5$ conotoxins (Figure 2), which include important residues for the binding to muscle-type nAChR. Notably, SII differs from the rest in two main ways: (1) it has Pro residue in place of expected Arg/Lys; (2) it has a long C-terminus. Structure-functional studies on SII are very scarce, except for one that characterized SII as possessing three disulfide bonds and no net positive charge [32].

\section{2. $\alpha 4 / 3$ Conotoxins}

Asp 5, Pro 6, Arg 7, and Trp 10 are critical residues of the ImI conotoxin, conferring its specificity for the $\alpha 7 \mathrm{nAChRs}$ [33]. 
Despite the fact that ImI and ImII conotoxins share a high sequence homology (9 of 12 amino acids are identical) (Figure 2), they were found to target different sites at the $\alpha 7$ $\mathrm{nAChR}$, since only ImI (and not ImII) showed competitive inhibition of the receptor when $\alpha$-bungarotoxin ( $\alpha$-Bgtx) was co-added [34]. Mutational studies revealed that the amino acid residue at position 6 (Pro in $\alpha$-Ctx ImI, Arg in $\alpha$-Ctx ImII) determines the selectivity for a specific site, whereas the amino acid residue in position 9 (Ala in $\alpha$-Ctx ImI, Arg in $\alpha$-Ctx ImII) confers each of the toxins its optimal affinity to bind to their corresponding sites at the $\alpha 7 \mathrm{nAChR}[34]$.

The selectivity and potency of $\alpha$-conotoxin RgIA for the $\alpha 9 \alpha 10$ subtype of nAChR is conferred by Arg 9 and Arg 13 residues [35]. It is also interesting to note that [3,12]dicarba RgIA is able to act specifically at $\alpha 9 \alpha 10 \mathrm{nAChRs}$, losing its effect on N-type calcium channels [36]. This analogue could potentially be used in a clinical trial for eliciting an effect on a single receptor subtype.

\section{3. $\alpha 4 / 4$ Conotoxins}

$\alpha$-conotoxin BuIA blocks $\alpha 6 / \alpha 3 \beta 2$ nAChRs with a significantly lower $\mathrm{IC}_{50}$ than $\alpha 4 \beta 2$ receptors [37]. In fact, there is a 40,000-fold difference between their $\mathrm{IC}_{50}$ values [37]. The five residues of the $\alpha 6$ subunit, Lys 85, Asp 187, Ile 188, Thr 198, and Tyr 205, were determined to be responsible for this effect [38].

It should be noted that $\alpha$-conotoxin BuIA on $\mathrm{nAChRs}$ with $\beta 4$ subunits have slow off-time when compared to corresponding $\mathrm{nAChRs}$ with $\beta 2$ subunits [37]. This implies that BuIA can discriminate between different $\beta$ subunits based on the time needed to unblock the receptor.

The $\alpha$-conotoxin BuIA [T5A; P6O] was found to be selective for $\alpha 6 \beta 4$ vs. $\alpha 6 \beta 2$ $\mathrm{nAChRs}$ [39]. It was mainly achieved by $\mathrm{P} 6 \mathrm{O}$ substitution, which resulted in a 2800 -fold increase of $\mathrm{IC}_{50}$ at $\alpha 6 / \alpha 3 \beta 2 \beta 3$ and only a 6-fold increase at $\alpha 6 / \alpha 3 \beta 4$ [39].

It is interesting to note that, though $\alpha$-conotoxins EIIA and PIB come from different Conus species, they are almost identical in sequence, except for one residue at the second position. Therefore, it is not surprising that they both have selectivity for muscle-type nAChRs [40]. This could be due to Asn 4, Pro 5, Ala 6, and Lys 9 residues located in the first and second loops, respectively, which were previously found to be critical for the muscle nAChR selectivity of $\alpha 3 / 5$ conotoxins [40].

\section{4. $\alpha 4 / 6$ Conotoxins}

Alanine scanning mutagenesis revealed three residues in the AuIB conotoxin (Gly 1, Pro 6, and Phe 9) that affect the inhibition of $\alpha 3 \beta 4$ nAChRs [41]. Gly 1 participates in the formation of a salt bridge between the N-terminus of the peptide and Asp 72 of the $\beta 4$ subunit. Hence, its substitution with alanine disrupted a favorable interaction of AuIB with the receptor. However, most of the inhibitory effect is elicited particularly by Pro 6 and Phe 9. It was elucidated that Pro 6 caused inhibition due to its effect on 3D structure of the peptide, whereas Phe 9 was responsible for the interaction with a two-residue binding pocket (Trp 59 and Lys 61) of the $\beta 4$ subunit [41].

ViIA is a unique $\alpha$-conotoxin that specifically targets the $\alpha 3 \beta 2 \mathrm{nAChR}$ subtype [42]. Structure-activity studies on the ViIA conotoxin revealed that Arg 1 and His 11 are critical residues for binding to the target effectively. Interestingly, a mutant ViIA[+16L] (a mutant with additional Leu residue at position 16) produced a 12-fold stronger interaction with $\alpha 3 \beta 2 \mathrm{nAChR}$ when compared to the native peptide. This was explained by hydrophobicity Leu residue conferred to the overall structure of the ViIA conotoxin [42].

The VnIB conotoxin selectively inhibits $\alpha 6 \beta 4$ nAChRs [43]. However, no structureactivity studies on this conopeptide have been carried out so far. It is hypothesized that all of the members of $\alpha 4 / 6$ conotoxins, including VnIB, exhibit $\beta 4$ subunit selectivity due to their common $4 / 6$ substructure. The selectivity of VnIB toward $\alpha 6$-containing nAChRs can potentially be explained by the five residues present in the second disulfide-loop, excluding Pro residue (YTKNPN) [43]. 
There are five residues (His 5, Pro 6, Val 7, Met 11, and Pro 13) of TxID critical for the inhibition of $\alpha 3 \beta 4$ and $\alpha 6 / \alpha 3 \beta 4 \mathrm{nAChRs}$ [44]. [S9A] TxID mutant was found to discriminate between the two receptor subtypes, having a 46-fold higher affinity to $\alpha 3 \beta 4$ than to $\alpha 6 / \alpha 3 \beta 4$ nAChRs [44].

\section{5. $\alpha 4 / 7$ Conotoxins}

Ala 11 and Gln 14 play a role in $\alpha 3 \beta 2$ selectivity of AnIB, whereas the C-terminal amidation and sulfation of Tyr 16 are responsible for $\alpha 7 \mathrm{nAChR}$ binding [45].

ArIB [V11L; V16D] is considered to be the most selective $\alpha 7 \mathrm{nAChR}$ antagonist to date $\left(\mathrm{IC}_{50}=1.09 \mathrm{nM}\right)[46]$.

Important residues conferring EI potency to bind mouse $\alpha 1 \beta 1 \delta \varepsilon \mathrm{nAChR}$ were found to be His 7, Pro 8, Met 12, and Pro 15. In addition, deletion of Arg1-Asn2-Hyp3 residues are also crucial, since their deletion causes a total loss of activity at muscle receptors [47]. [S13A] EI mutant exhibited increased potency and selectivity for $\alpha 1 \beta 1 \delta \varepsilon$ nAChRs [47].

GIC is a very interesting conotoxin from a research standpoint, since it exhibits extreme potency and selectivity towards $\alpha 3 \beta 2 \mathrm{nAChRs}\left(\mathrm{IC}_{50}=1.1 \mathrm{nM}\right)$ [48]. His 5 and Gln 13 were found to be the most important residues that confer GIC its potency and selectivity, respectively. In addition, Ala 7, Asn 11, and Asn 12 residues of the peptide were involved in binding to the principal site of the receptor [48].

Ala 10, Val 13 and Val 18 are important residues of the GID conotoxin, conferring it selectivity for $\alpha 4 \beta 2$ over $\alpha 3 \beta 2$ nAChRs [49]. In particular, GID[V18N] analog exhibits the highest selectivity for $\alpha 4 \beta 2$, with no inhibitory effect on the $\alpha 3 \beta 2$ subtype [49].

The structure-functional study conducted to the Lola conotoxin found that its Asp18 residue is critical for the selectivity of the peptide for neuronal vs. muscle subtype $n A C h R s$ [50]. This was evident from the observation that Lo1a- $\Delta \mathrm{D}$ and Lo1a-RRR analogues, which either lacked Asp 18 or had it replaced with 3 Arg residues, respectively, acquired affinity for the adult muscle subtype $\alpha 1 \beta 1 \delta \varepsilon$, aside from $\alpha 7$ receptors [50].

Ser- 1 and Gly 2 are important residues for the affinity of LsIA to $\alpha 3 \beta 2$ and $\alpha 7$ $\mathrm{nAChRs} \mathrm{[51].} \mathrm{In} \mathrm{addition,} \mathrm{carboxylation} \mathrm{of} \mathrm{the} \mathrm{C-terminus} \mathrm{of} \mathrm{LsIA} \mathrm{resulted} \mathrm{in} \mathrm{its} \mathrm{selectivity}$ for $\alpha 3 \beta 2$ over $\alpha 7$ to increase 9-fold [51].

Selectivity of the Lt1.3 conotoxin for $\alpha 3 \beta 2$ receptors is attributed to a small hydrophobic Gly 10 residue, whereas Asn 11, Asn 12, Pro 13, Tyr 14, and Phe 15 residues contribute to the receptor binding [52].

His 5, Pro 6, Ala 7, and His 12 of LvIA are important residues that interact with $\alpha 3-$ containing $\mathrm{nAChRs}$ [53]. LvIA exhibits unusual selectivity toward $\alpha 3 \beta 2$ vs. $\alpha 6 / \alpha 3 \beta 2 \beta 3$ nAChRs due to Asn 9 and Asp 11 residues [54].

Asp 5, Pro 6, and His 12 are the main residues of the MII conotoxin, which confers its potency for binding to the rat $\alpha 3 \beta 2 \mathrm{nAChR}$ subtype [55]. The MII [H9A; L15A] analog of $\alpha$ conotoxin $\mathrm{MII}$ is selective towards $\alpha 6$-containing receptors $\left(\mathrm{IC}_{50}\right.$ on rat $\left.\alpha 6 / \alpha 3 \beta 2 \beta 3=2.4 \mathrm{nM}\right)$, and can discriminate between $\alpha 6$ and $\alpha 3$ subunits [56].

Mr1.7 [E2A] is potent and selective for the $\alpha 3 \beta 2 \mathrm{nAChR}$ subtype, with no inhibitory effect on other subtypes [57]. However, the substitution of Ser 12 with Ala results in the loss of selectivity to $\alpha 3 \beta 2$, with new binding ability to other subtypes $(\alpha 3 \beta 4, \alpha 2 \beta 4$, and

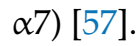

The PeIA conotoxin can be made $>15,000$-fold more potent on $\alpha 6 / \alpha 3 \beta 2 \beta 3$ vs. $\alpha 3 \beta 2$ nAChRs via substituting Asn 11 with either Lys or Arg [58]. On the contrary, PeIA-4566, which is a synthetic peptide composed of non-natural amino acids, targets $\alpha 3 \beta 2$ over $\alpha 6 / \alpha 3 \beta 2 \beta 3$, with a 300-fold difference in potency [59]. PeIA [S9H; V10A; E14N] analog blocks $\alpha 6 / \alpha 3 \beta 2 \beta 3$ and $\alpha 6 / \alpha 3 \beta 4$ nicotinic receptors with $\mathrm{IC}_{50}$ values of $223 \mathrm{pM}$ and $65 \mathrm{nM}$, respectively [60]. Thus, it can be concluded that PeIA [S9H; V10A; E14N] discriminates between $\alpha 6 \beta 2$ and $\alpha 6 \beta 4$ nAChRs.

Residues from Leu 5 to Pro 13 and Tyr 15 are important residues of PnIA, conferring its inhibitory effect on $\alpha 7 \mathrm{nAChRs}$ [61]. In addition, the PnIA [A10L] mutant is able to exclusively bind $\alpha 7 \mathrm{nAChRs}$ [62]. 
The RegIIA [N11A; N12A] analog selectively blocks $\alpha 3 \beta 4$ vs. $\alpha 3 \beta 2$ nAChRs, with a 1000-fold difference in potency [63].

TxIB is unique due to its ability to selectively bind $\alpha 6 / \alpha 3 \beta 2 \beta 3 \mathrm{nAChRs,} \mathrm{while} \mathrm{lacking}$ any capability to bind to other receptor subtypes [64]. However, structure-functional studies accounting for this have not been conducted yet.

It is generally accepted that $\alpha$-Ctxs are antagonists of nAChRs, but MrIC (PECCTHPACHVSNPELC), which is a peptide variant of Mr1.7, plays a full agonist role of endogenous human $\alpha 7 \mathrm{nAChRs}$ in the presence of PNU (positive allosteric modulator of $\alpha 7 \mathrm{nAChR}$ subtype) [65]. It is suggested that the Pro residue in the $\mathrm{N}$-terminus of the peptide has a role in binding $\alpha 7 \mathrm{nAChR}$ [65].

It was found that Asp 5 to Arg 7, and Asp 11 to Ile 15, are critical residues for the inhibitory effect of Vc1.1 at the $\alpha 9 \alpha 10 \mathrm{nAChR}$ subtype [66]. In addition, mutations at positions 4 and 9 (substitution of Ser 4 with either Lys or Arg and substitution of Asn 9 with either Ala, Leu, or Ile) increased the potency of Vc1.1 at $\alpha 9 \alpha 10$ nAChRs [66].

\subsection{Therapeutic Potential of $\alpha$-Conotoxins}

Due to the fact that $\mathrm{nAChRs}$ are implicated in a range of pathological conditions, $\alpha$-conotoxins targeting nAChRs pose themselves as attractive candidates for drug development [67-69]. For example, $\alpha$-conotoxins RgIA and Vc1.1 demonstrate the analgesic effect in animal models of neuropathic pain [14,70-76]. Such analgesic effect works through targeting $\alpha 9 \alpha 10 \mathrm{nAChRs}$. The mechanism of analgesia mediated by RgIA and Vc1.1 conotoxins is not currently clear, but there are indications that it involves immune-mediated pathways.

RgIA was shown to be potent in reducing mechanical allodynia and oxaliplatininduced hypersensitivity to thermal and mechanical stimuli [77], as well as accelerating the recovery of nerve damage following chronic constriction injury (CCI) [70]. Other than alleviating neuropathic pain, $\operatorname{RgIA}$ was also shown to be able to reduce the severity of dextran sodium sulfate-induced colitis in an animal model [78].

Vc1.1 was shown to reduce mechanical allodynia in rats with diabetic neuropathy induced by streptozotocin, and in rats with CCI [14,74]. Vc1.1 reduced mechanical hyperalgesia in rats with peripheral nerve ligation when the toxin was injected intramuscularly [75].

Another $\alpha$-conotoxin with a potential therapeutic application due to its antitumor activity is TxID. The toxin inhibited the growth of lung cancer cells [79].

The results from in vitro and animal studies serve as an encouragement for drug development. There are, however, hindrances along the way [80], which stem from the peptidic nature of the toxins, the potential off-target effects, and different potencies on human receptors vs. rodent ones. For example, Vc1.1 was discontinued from phase II human clinical trials due to its low affinity on human $\alpha 9 \alpha 10 \mathrm{nAChRs}$ [15] ( $\mathrm{IC}_{50}$ on rat $\alpha 9 \alpha 10$ is $20-100 \mathrm{nM}$, on human $\alpha 9 \alpha 10$ is $1 \mu \mathrm{M}$ ).

Table 1. The $\alpha$-conotoxins mentioned in the main text are shown, together with their targets and potencies.

\begin{tabular}{ccccc}
\hline$\alpha$-Conotoxin & Species & Target and $\mathrm{IC}_{\mathbf{5 0}} / \mathbf{K i}$ & Reference & UniProt/PDB \\
\hline Ac1.1a & C. achatinus & $\mathrm{m}(\alpha 1) 2 \beta 1 \delta \gamma\left(\mathrm{IC}_{50}=36 \mathrm{nM}\right)$ & [27] & P0CAQ4/n.d. \\
\hline Ac1.1b & C. achatinus & $\mathrm{m}(\alpha 1) 2 \beta 1 \delta \gamma\left(\mathrm{IC}_{50}=26 \mathrm{nM}\right)$ & [27] & P0CAQ5/n.d. \\
\hline CIA & C. catus & $\begin{array}{c}\mathrm{r}(\alpha 1) 2 \beta 1 \delta \gamma\left(\mathrm{IC}_{50}=5.7 \mathrm{nM}\right) \\
\mathrm{r} \alpha 3 \beta 2\left(\mathrm{IC}_{50}=2.06 \mu \mathrm{M}\right)\end{array}$ & [31] & D4HPD6/n.d. \\
\hline
\end{tabular}


Table 1. Cont.

\begin{tabular}{|c|c|c|c|c|}
\hline$\alpha$-Conotoxin & Species & Target and $\mathrm{IC}_{50} / \mathrm{Ki}$ & Reference & UniProt/PDB \\
\hline GI & C. geographus & $\begin{array}{c}\text { Torpedo californica } \\
\left(\mathrm{IC}_{50} \alpha / \gamma \text { site }=4.5 \mathrm{nM}\right) \\
\left(\mathrm{IC}_{50} \alpha / \delta \text { site }=87 \mathrm{nM}\right) \\
\mathrm{m}(\alpha 1) 2 \beta 1 \delta \gamma \\
\left(\mathrm{IC}_{50} \alpha / \delta \text { site }=1.3 \mathrm{nM}\right) \\
\left(\mathrm{IC}_{50} \alpha / \gamma \text { site }=60 \mu \mathrm{M}\right) \\
\mathrm{r} \alpha 9 \alpha 10\left(\mathrm{IC}_{50}=9.35 \mu \mathrm{M}\right)\end{array}$ & {$[29,30]$} & P01519/1XGA \\
\hline MI & C. magus & $\mathrm{m}(\alpha 1) 2 \beta 1 \delta \gamma\left(\mathrm{IC}_{50}=0.4 \mathrm{nM}\right)$ & [26] & P01521/n.d. \\
\hline SIA & C. striatus & $\begin{array}{c}\mathrm{m}(\alpha 1) 2 \beta 1 \delta \gamma \\
\left(\mathrm{IC}_{50}=2.6 \mathrm{nM}\right) \\
\left(\mathrm{IC}_{50}=2.3 \mu \mathrm{M}\right) \\
\end{array}$ & [28] & P28878/n.d. \\
\hline SII & C. striatus & $\mathrm{m}(\alpha 1) 2 \beta 1 \delta \gamma\left(\mathrm{IC}_{50}=18 \mu \mathrm{M}\right)$ & [28] & P28879/6ОТВ \\
\hline $\operatorname{ImI}$ & C.imperialis & $\begin{array}{c}\mathrm{h} \alpha 3 \beta 2\left(\mathrm{IC}_{50}=40.8 \mathrm{nM}\right) \\
\mathrm{h} \alpha 3 \beta 4\left(\mathrm{IC}_{50}=3.39 \mu \mathrm{M}\right) \\
\mathrm{h} \alpha 7\left(\mathrm{IC}_{50}=595 \mathrm{nM}\right) \\
\mathrm{r} \alpha 7\left(\mathrm{IC}_{50}=191 \mathrm{nM}\right) \\
\mathrm{r} \alpha 7\left(\mathrm{IC}_{50}=69.3 \mathrm{nM}\right)\end{array}$ & {$[34,81]$} & P50983/1CNL \\
\hline ImII & C.imperialis & $\begin{array}{c}\mathrm{h}(\alpha 1) 2 \beta 1 \delta \varepsilon\left(\mathrm{IC}_{50}=1.06 \mu \mathrm{M}\right) \\
\mathrm{h} \alpha 3 \beta 2\left(\mathrm{IC}_{50}=9.61 \mu \mathrm{M}\right) \\
\mathrm{h} \alpha 7\left(\mathrm{IC}_{50}=571 \mathrm{nM}\right) \\
\mathrm{r} \alpha 7\left(\mathrm{IC}_{50}=441 \mathrm{nM}\right)\end{array}$ & {$[34,81]$} & Q8I6R5/n.d. \\
\hline RgIA & C. regius & $\begin{array}{c}\mathrm{r} \alpha 9 \alpha 10\left(\mathrm{IC}_{50}=4.55-5.19 \mathrm{nM}\right) \\
\mathrm{r} \alpha 7\left(\mathrm{IC}_{50}=4.66 \mu \mathrm{M}\right)\end{array}$ & [82] & P0C1D0/2JUT \\
\hline BuIA & C. bullatus & $\begin{array}{c}\mathrm{r} \alpha 6 / \alpha 3 \beta 2\left(\mathrm{IC}_{50}=0.3 \mathrm{nM}\right) \\
\mathrm{r} \alpha 6 / \alpha 3 \beta 2 \beta 3\left(\mathrm{IC} \mathrm{C}_{50}=0.46 \mathrm{nM}\right) \\
\mathrm{r} \alpha 6 / \alpha 3 \beta 4\left(\mathrm{IC}_{50}=1.5-2.1 \mathrm{nM}\right) \\
\mathrm{r} \alpha 2 \beta 4\left(\mathrm{IC}_{50}=121 \mathrm{nM}\right) \\
\mathrm{r} \alpha 3 \beta 2\left(\mathrm{IC}_{50}=5.7 \mathrm{nM}\right) \\
\mathrm{r} \alpha 3 \beta 4\left(\mathrm{IC}_{50}=28 \mathrm{nM}\right) \\
\mathrm{r} \alpha 4 \beta 4\left(\mathrm{IC}_{50}=70 \mathrm{nM}\right) \\
\mathrm{r} \alpha 7\left(\mathrm{IC}_{50}=272 \mathrm{nM}\right)\end{array}$ & {$[37,39]$} & P69657/2I28 \\
\hline EIIA & C. ermineus & $\begin{array}{c}\text { Torpedo }(\mathrm{Ki}=0.46-105 \mathrm{nM}) \\
\alpha 7-5 \mathrm{HT} 3(\mathrm{Ki}>>1000 \mathrm{nM}) \\
\alpha 3 \beta 2(\mathrm{Ki}>>1000 \mathrm{nM}) \\
\alpha 4 \beta 2(\mathrm{Ki}>>1000 \mathrm{nM})\end{array}$ & [40] & D4HRK4/n.d. \\
\hline PIB & C. purpurascens & $\begin{array}{l}\mathrm{m}(\alpha 1) 2 \beta 1 \delta \varepsilon\left(\mathrm{IC}_{50}=36 \mathrm{nM}\right) \\
\mathrm{m}(\alpha 1) 2 \beta 1 \delta \gamma\left(\mathrm{IC}_{50}=45 \mathrm{nM}\right)\end{array}$ & [83] & P0C351/n.d. \\
\hline AuIB & C. aulicus & $\begin{array}{c}\alpha 3 \beta 2 / \alpha 3 \beta 4 \text { (intracardiac ganglia) } \\
\left(\mathrm{IC} \mathrm{C}_{50}=1.2 \mathrm{nM}\right) \\
\mathrm{r} \alpha 3 \beta 4 \text { (recombinant) } \\
\left(\mathrm{IC}_{50}=750-966 \mathrm{nM}\right)\end{array}$ & {$[84,85]$} & P56640/1MXN \\
\hline ViIA & C. virgo & $\mathrm{r} \alpha 3 \beta 2\left(\mathrm{IC}_{50}=845.5 \mathrm{nM}\right)$ & [42] & F5C0A0/n.d. \\
\hline VnIB & C. ventricosus & $\begin{array}{c}\mathrm{r} \alpha 6 \beta 4\left(\mathrm{IC}_{50}=12 \mathrm{nM}\right) \\
\mathrm{r} \alpha 6 / \alpha 3 \beta 4\left(\mathrm{IC}_{50}=18 \mathrm{nM}\right) \\
\mathrm{r} \alpha 3 \beta 4\left(\mathrm{IC}_{50}=320 \mathrm{nM}\right) \\
\mathrm{r} \alpha 6 / \alpha 3 \beta 2 \beta 3\left(\mathrm{IC}_{50}=4000 \mathrm{nM}\right) \\
\mathrm{h} \alpha 6 / \alpha 3 \beta 4\left(\mathrm{IC}_{50}=5.3 \mathrm{nM}\right)\end{array}$ & [43] & A0A4P8XV20/n.d. \\
\hline TxID & C. textile & $\begin{array}{c}\mathrm{r} \alpha 3 \beta 4\left(\mathrm{IC}_{50}=12.5 \mathrm{nM}\right) \\
\mathrm{r} \alpha 6 / \alpha 3 \beta 4\left(\mathrm{IC}_{50}=94 \mathrm{nM}\right)\end{array}$ & {$[64]$} & K8DWB5/n.d. \\
\hline AnIB & C. anemone & $\begin{array}{l}\mathrm{r} \alpha 3 \beta 2\left(\mathrm{IC}_{50}=0.3 \mathrm{nM}\right) \\
\mathrm{r} \alpha 7\left(\mathrm{IC}_{50}=76 \mathrm{nM}\right)\end{array}$ & [45] & P0C1V7/n.d. \\
\hline
\end{tabular}


Table 1. Cont.

\begin{tabular}{|c|c|c|c|c|}
\hline$\alpha$-Conotoxin & Species & Target and $\mathrm{IC}_{50} / \mathrm{Ki}$ & Reference & UniProt/PDB \\
\hline ArIA & C. arenatus & $\begin{array}{c}\mathrm{r} \alpha 7\left(\mathrm{IC}_{50}=6 \mathrm{nM}\right) \\
\mathrm{r} \alpha 3 \beta 2\left(\mathrm{IC}_{50}=18 \mathrm{nM}\right)\end{array}$ & [46] & P0C8R2/n.d. \\
\hline ArIB & C. arenatus & $\begin{array}{c}\mathrm{r} \alpha 7\left(\mathrm{IC}_{50}=1.8 \mathrm{nM}\right) \\
\mathrm{r} \alpha 6 / \alpha 3 \beta 2 \beta 3\left(\mathrm{IC}_{50}=6.45 \mathrm{nM}\right) \\
\mathrm{r} \alpha 3 \beta 2\left(\mathrm{IC}_{50}=60.1 \mathrm{nM}\right)\end{array}$ & [46] & P0C8R2/n.d. \\
\hline CIB & C.catus & $\begin{array}{c}\mathrm{r} \alpha 3 \beta 2\left(\mathrm{IC}_{50}=128.9 \mathrm{nM}\right) \\
\mathrm{r} \alpha 7\left(\mathrm{IC}_{50}=1.51 \mu \mathrm{M}\right)\end{array}$ & [24] & P0DPT2/n.d. \\
\hline EI & C. ermineus & $\begin{array}{c}\mathrm{m}(\alpha 1) 2 \beta 1 \delta \varepsilon \\
\left(\mathrm{IC}_{50(1)}=9.4 \mathrm{nM}\right) \\
\left(\mathrm{IC}_{50(2)}=280 \mathrm{nM}\right) \\
\text { Torpedo } \\
\left(\mathrm{IC}_{50(1)}=0.41 \mathrm{nM}\right) \\
\left(\mathrm{IC}_{50(2)}=190 \mathrm{nM}\right)\end{array}$ & [86] & P50982/1K64 \\
\hline GIC & C. geographus & $\begin{array}{l}\mathrm{h} \alpha 3 \beta 2\left(\mathrm{IC}_{50}=1.1 \mathrm{nM}\right) \\
\mathrm{h} \alpha 3 \beta 4\left(\mathrm{IC}_{50}=755 \mathrm{nM}\right) \\
\mathrm{h} \alpha 4 \beta 2\left(\mathrm{IC}_{50}=309 \mathrm{nM}\right)\end{array}$ & [87] & Q86RB2/1UL2 \\
\hline GID & C. geographus & $\begin{array}{c}\mathrm{r} \alpha 3 \beta 2\left(\mathrm{IC}_{50}=3.1 \mathrm{nM}\right) \\
\mathrm{r} \alpha 7\left(\mathrm{IC}_{50}=4.5 \mathrm{nM}\right) \\
\mathrm{r} \alpha 4 \beta 2\left(\mathrm{IC}_{50}=152 \mathrm{nM}\right)\end{array}$ & {$[88,89]$} & P60274/1MTQ \\
\hline Lo1a & C. longurionis & $\alpha 7\left(\mathrm{IC}_{50}=3.24 \mu \mathrm{M}\right)$ & {$[50]$} & X1WB75/2MD6 \\
\hline LsIA & C. limpusi & $\begin{array}{c}\alpha 3 \beta 2\left(\mathrm{IC}_{50}=10 \mathrm{nM}\right) \\
\alpha 3 \alpha 5 \beta 2\left(\mathrm{IC}_{50}=31 \mathrm{nM}\right) \\
\alpha 7\left(\mathrm{IC}_{50}=10 \mathrm{nM}\right)\end{array}$ & [51] & P0DL68/n.d. \\
\hline LtIA & C. litteratus & $\begin{array}{c}\alpha 3 \beta 2\left(\mathrm{IC}_{50}=9.8 \mathrm{nM}\right) \\
\alpha 6 / \alpha 3 \beta 2 \beta 3\left(\mathrm{IC}_{50}=84.4 \mathrm{nM}\right) \\
\alpha 6 / \alpha 3 \beta 4\left(\mathrm{IC}_{50}=6 \mu \mathrm{M}\right)\end{array}$ & [90] & Q2I2R8/n.d. \\
\hline Lt1.3 & C. litteratus & $\mathrm{r} \alpha 3 \beta 2\left(\mathrm{IC}_{50}=44.8 \mathrm{nM}\right)$ & [52] & n.d. \\
\hline LvIA & C. lividus & $\begin{array}{c}\alpha 3 \beta 2\left(\mathrm{IC}_{50}=8.7 \mathrm{nM}\right) \\
\alpha 6 / \alpha 3 \beta 2 \beta 3\left(\mathrm{IC}_{50}=108 \mathrm{nM}\right) \\
\alpha 6 / \alpha 3 \beta 4\left(\mathrm{IC}_{50}=121 \mathrm{nM}\right) \\
\alpha 3 \beta 4\left(\mathrm{IC}_{50}=148 \mathrm{nM}\right) \\
\alpha 7\left(\mathrm{IC}_{50}=3 \mu \mathrm{M}\right) \\
\mathrm{h} \alpha 3 \beta 2\left(\mathrm{IC}_{50}=17.5 \mathrm{nM}\right) \\
\mathrm{h} \alpha 6 / \alpha 3 \beta 2 \beta 3\left(\mathrm{IC}_{50}=5.34 \mu \mathrm{M}\right)\end{array}$ & [53] & L8BU87/2MDQ \\
\hline MII & C. magus & $\begin{array}{c}\alpha 6 / \alpha 3 \beta 2 \beta 3\left(\mathrm{IC}_{50}=0.4 \mathrm{nM}\right) \\
\alpha 3 \beta 2\left(\mathrm{IC}_{50}=0.5 / 3.7 \mathrm{nM}\right)\end{array}$ & {$[55,56,91]$} & $\mathrm{P} 56636 / 1 \mathrm{M} 2 \mathrm{C}$ \\
\hline Mr1.7 & C. marmoreus & $\begin{array}{c}\mathrm{r} \alpha 3 \beta 2\left(\mathrm{IC}_{50}=53.1 \mathrm{nM}\right) \\
\mathrm{r} \alpha 9 \alpha 10\left(\mathrm{IC}_{50}=185.7 \mathrm{nM}\right) \\
\mathrm{r} \alpha 6 / \alpha 3 \beta 2 \beta 3\left(\mathrm{IC}_{50}=284.2 \mathrm{nM}\right)\end{array}$ & [57] & F6LPN3/n.d. \\
\hline PeIA & C. pergrandis & $\begin{array}{c}\mathrm{r} \alpha 9 / \alpha 10\left(\mathrm{IC}_{50}=6.9 \mathrm{nM}\right) \\
\mathrm{r} \alpha 7\left(\mathrm{IC}_{50}=1.8 \mu \mathrm{M}\right) \\
\mathrm{r} \alpha 3 \beta 2\left(\mathrm{IC}_{50}=23 \mathrm{nM}\right) \\
\mathrm{r} \alpha 3 \beta 4\left(\mathrm{IC}_{50}=480 \mathrm{nM}\right)\end{array}$ & [92] & Q1L777/n.d. \\
\hline PnIA & C. pennaceus & $\begin{array}{l}\mathrm{r} \alpha 3 \beta 2\left(\mathrm{IC}_{50}=9.56 \mathrm{nM}\right) \\
\quad \mathrm{r} \alpha 7\left(\mathrm{IC}_{50}=252 \mathrm{nM}\right)\end{array}$ & [61] & P50984/1PEN \\
\hline RegIIA & C. regius & $\begin{array}{c}\mathrm{r} \alpha 3 \beta 4\left(\mathrm{IC}_{50}=97 \mathrm{nM}\right) \\
\mathrm{r} \alpha 3 \beta 2\left(\mathrm{IC}_{50}=33 \mathrm{nM}\right) \\
\mathrm{h} \alpha 7\left(\mathrm{IC}_{50}=103 \mathrm{nM}\right)\end{array}$ & [93] & P85013/n.d. \\
\hline
\end{tabular}


Table 1. Cont.

\begin{tabular}{|c|c|c|c|c|}
\hline$\alpha$-Conotoxin & Species & Target and $\mathrm{IC}_{50} / \mathrm{Ki}$ & Reference & UniProt/PDB \\
\hline TxIB & C. textile & $\mathrm{r} \alpha 6 / \alpha 3 \beta 2 \beta 3\left(\mathrm{IC}_{50}=28 \mathrm{nM}\right)$ & [64] & K4RNX9/2LZ5 \\
\hline Vc1.1 & C. victoriae & $\begin{array}{c}\mathrm{r} \alpha 9 \alpha 10\left(\mathrm{IC}_{50}=109 \mathrm{nM}\right) \\
\mathrm{h} \alpha 9 \alpha 10\left(\mathrm{IC}_{50}=549 \mathrm{nM}\right) \\
\mathrm{r} \alpha 6 / \alpha 3 \beta 2 \beta 3\left(\mathrm{IC}_{50}=140 \mathrm{nM}\right) \\
\mathrm{r} \alpha 3 \beta 4\left(\mathrm{IC}_{50}=4.2 \mu \mathrm{M}\right) \\
\mathrm{r} \alpha 3 \beta 2\left(\mathrm{IC}_{50}=7.3 \mu \mathrm{M}\right)\end{array}$ & {$[66,94]$} & P69747/2H8S \\
\hline
\end{tabular}

\section{Snake Venoms as a Source of Toxins Acting on Acetylcholine Receptors}

Snakes are a rich source of ligands targeting $n A C h R s$. The neurotoxins of snake origin were characterized long ago and include $\alpha$-Bgtx from Bungarus meltinctus and $\alpha$-cobratoxin $(\alpha-\mathrm{Cbtx})$ from Naja naja siamensis. The biologically active toxins in snake venoms can be organized into molecules with enzymatic or without enzymatic activities. Many snake neurotoxins of non-enzymatic action possess a conserved structural feature consisting of three-finger loops, where $\beta$-sheet fingers protrude from a globular hydrophobic core coordinated by disulfide bonds [95]. Neurotoxins targeting postsynaptic nAChRs are called $\alpha$-neurotoxins ( $\alpha$-NTX) [96]. Depending on the length and number of disulfide bridges, three-finger $\alpha$-neurotoxins are divided into short-chain toxins (type I) and long-chain toxins (type II). Long-chain toxins contain 66-75 amino-acids and ten cysteines, whereas short-chain toxins have 60-62 amino-acids and eight cysteines. Other than three-fingered neurotoxins with a typical structure, more and more toxins with alternate structures are being discovered. For example, non-conventional three-finger neurotoxins are similar to long-chain $\alpha$-NTX in their length and number of disulfide bonds; however, the fifth disulfide bond is located within finger I of the toxin, unlike in finger II within longchain $\alpha$-NTX [97]. The toxins within this group include "weak toxin" WTX [98] and candoxin [99]. Some snake toxins can form homo- or heterodimers. Homodimers of short-chain three-finger $\alpha$-NTX include fulditoxin and haditoxin. Homodimers of longchain $\alpha$-NTX include the $\alpha$-cobratoxin dimer $[100,101]$. Homodimers can be formed as a result of covalent interactions, as in $\alpha$-cobratoxin, or noncovalent interactions, as in к-bungarotoxin, fulditoxin, and haditoxin [101,102]. Heterodimeric toxins include irditoxin with intermolecular disulfide bonds [103].

\subsection{Long-Chain Three-Finger $\alpha$-NTXs}

Long-chain three-finger $\alpha$-NTs interact with muscle and neuronal nAChRs. To the neuronal $\alpha 7$ receptor, these toxins bind with high affinity, Kd values at $10^{-9}$ to $10^{-8} \mathrm{M}$ [104]. The residues within finger II of the toxin were shown to be important for binding to this receptor type. The mode of interaction of two long-chain three-finger $\alpha$-NTXs, $\alpha$ bungarotoxin and $\alpha$-cobratoxin, will be considered below.

$\alpha$-bungarotoxin contains 74 amino-acids and 5 disulfide bonds. The toxin was isolated in 1963 by Chang and Lee [105] from a Taiwan banded krait Bungarus multicinctus, and helped in the characterization of muscle-type nAChRs [106]. Original discovery of the toxin demonstrated its paralytic effect in rodent muscle preparation, and later it was shown that the toxin targets muscle $\mathrm{nAChRs}$ with high affinity $(\mathrm{Kd} \sim 5 \mathrm{nM})$, acting as a competitive antagonist in an irreversible fashion [104]. The toxin also blocks Torpedo acetylcholine receptor in the irreversible fashion [107]. Besides targeting muscle-type receptor, it also has high affinity towards homomeric neuronal receptors, such as $\alpha 7$ and $\alpha 9$, with nanomolar affinity [108]. An NMR structure of the toxin (PDB: 1KFH) shows three fingers projecting from the globular core, shaped by four disulfide bonds, with an additional disulfide bond within finger II. Structure-functional studies revealed significance of cation- $\pi$ interaction in stabilizing the toxin within the ligand-binding site. Arg 36 plays a major role in toxin binding to muscle receptor type, as well as for neuronal receptor type [109]. This is 
due to similarities in the structure of guanidinium group within Arg 36 and quaternary ammonium of acetycholine, which directs toxins into the agonist binding site.

Multiple crystal structures of the toxin bound to its target were solved, which helped in understanding of the mode of toxin-ligand interaction by revealing the orientation of the toxin within binding site of the receptor. Moreover, $1.94 \AA$ crystal structure of $\alpha$-Bgtx bound to extracellular domain of $\alpha 1$ subunit of mouse muscle receptor is available (PDB: 2QC1) [110], which reveals the N-glycosylated Asn 141 on the receptor side, with oligosaccharide composed of two $\mathrm{N}$-acetylglucosamines (GlcNAc 2-3) and eight mannoses (Man 4-11), and forming hydrogen bonds with the toxin. The study demonstrated the orientation of the toxin within an aromatic cage of the ligand-binding interface. Finger I is surrounded by loop C and carbohydrate; the tip of finger II of the toxin is oriented into the ligand-binding site made up by loops A, B, and C on the receptor side, and finger III is away from the receptor. Arg 36 and Phe 32 within finger II on the toxin side form a cation- $\pi$ stack and oppose Tyr 198 from the receptor side in a "face-to-face" fashion. Two other tyrosines on the receptor side, Tyr 190 and Tyr 93, are also oriented towards Arg 36 and Phe 32, but face their edges. The structure also revealed hydrogen bonds between Arg 36, Thr 148, and Cys 192. Despite the wealth of information obtained from this crystal structure, the lack of adjacent subunit obscures the entire picture. Additionally, Trp 149 to Arg substitution, which was performed for crystallization purposes, removed Trp, which is important for toxin-receptor interaction.

The crystal structure of the $\alpha$-Bgtx bound to human $\alpha 7-\mathrm{AChBP}$ chimera resolved to $3.5 \AA$ A provided insight into the toxin interaction with adjacent subunits within a ligandbinding interface (PDB: 4HQP), where loop C of the receptor made contact with finger II of the toxin [111]. Particularly, Tyr 184, which is equivalent to Tyr 190 in mouse $\alpha 1$ subunit, is oriented towards the edge of cation- $\pi$ stack, formed by Arg 36 and Phe 32 . This is analogous to the earlier crystal structure. Tyr 184 is itself hydrogen-bonded through hydroxyl-group, with Asp 30 of the $\alpha$-Bgtx. Other residues from loop A (Tyr 91), loop B (Trp 145), and loop C (Tyr 191, Arg 182) also contribute to the toxin binding.

The crystal structure of $\alpha$-Bgtx complexed with the extracellular domain of $\alpha 9$ subunit at $2.7 \AA$ was solved (PDB: $4 \mathrm{UY} 2$ ), and it revealed the mode of interaction between the toxin and a principal subunit of the receptor. Thus, Arg 36 and Phe 32 of finger II of the $\alpha$-Bgtx are positioned deeply in the ligand-binding site of the $\alpha 9$ subunit, where they interact with residues of loops A, B, and C. Particularly, Arg 36 makes a cation- $\pi$ interaction and hydrogen bond with Tyr 95. Asp 30 forms a hydrogen bond with Tyr 192. Finger I interacts with loop C, with Val 40 forming a hydrogen bond with Ser 191. Finger III is oriented away from the ligand-binding site. Due to the fact that only a principle subunit interface is revealed by the structure, the contribution of the complementary subunit is not seen [112].

The Cryo-EM structure of $\alpha$-Bgtx complexed with native receptor from Torpedo electric organ (PDB: 6UWZ) revealed details of the toxin-receptor interaction [113] with $2.7 \AA$ resolution. The structure revealed residues on $\alpha-\delta$ and $\alpha-\gamma$ interfaces important for binding. The study highlighted the involvement of residues within complementary side on the ligand-binding interface, particularly within loop F. The structure showed the penetration of finger II of the toxin deep into the ACh binding pocket, where it makes contact with Tyr 93, Tyr 190, and Tyr 198 of the $\alpha$ subunit. Similar to the previous studies, Arg 36 forms a cation- $\pi$ interaction with Tyr 198 of the principal receptor subunit and Phe 32 of the toxin.

$\alpha$-cobratoxin is a 71 amino-acid-long toxin from the Indo-Chinese spitting cobra Naja naja siamensis which demonstrates curarimimetic activity. Residues important for binding to muscle-type receptor include Lys 23, Trp 25, Asp 27, Phe 29, Arg 33, and Lys 49. In addition, mutational studies revealed the importance of Arg 36 and Phe 65 for binding to $\alpha 7 \mathrm{nAChRs}$ and the Torpedo receptor [114], with some residues specific for binding to the $\alpha 7$ receptor (Ala 28, Lys 35, Cys 26, and 30), while others were specific for binding to the Torpedo receptor (Lys 23, Lys 49). The double-mutant cycle analysis for $\alpha$-Cbtx interaction with the $\alpha$ receptor revealed Phe 29-Trp 54 coupling [115]. The crystal structure of $\alpha$ - 
cobratoxin complexed with AChBP from Lymnaea stagnalis [116] revealed more details of a toxin-receptor interaction, where the toxin inserts its finger II deep into the ligand-binding pocket, with Phe29 and Arg33 of the toxin mimicking acetylcholine at the interface between two subunits. Phe29 and Arg33 engage in hydrophobic and aromatic interactions with AChBP Trp53, Tyr185, Tyr192, and Trp143. Additionally, Trp25, Asp27, Ala28, and Ile32 are close to Tyr185 in the principle subunit interface of AChBP and Glu163, Glu55, Leu112, Met114, and Tyr164 in a neighboring complementary subunit. Possible interactions could involve Ser31, Cys26, and Cys30 within finger II of the toxin, and AChBP Ser159-Tyr164 in a complementary subunit on the receptor side. The toxin displaces loop $C$ of the subunit. $\alpha \delta$-bungarotoxin- 1 is a 73 amino-acid-long toxin isolated from Bungarus candidus, with five disulfide bonds and inhibitory activity in muscle and neuronal $\alpha 7 \mathrm{nAChRs}$. Unlike $\alpha$-Bgtx, $\alpha \delta$-Bgtx binds to the target receptor in a reversible manner. Binding affinities are higher at the $\alpha-\delta$ interface than they are at the $\alpha-\gamma$ or $\alpha-\varepsilon$ interfaces [117]. The reason for such selectivity could be due to the shorter finger I, and thus a smaller number of contacts with the receptor interface, as well as fewer positively charged amino acids within finger II of the toxin.

Drysdalin is a long-chain NTX with 87 amino acids. It has five disulfide bonds and possesses curarimimetic activity with the irreversible inhibition of muscle receptors. The toxin demonstrates nanomolar affinity towards rodent muscle $(\alpha 1) 2 \beta 1 \delta \varepsilon$, as well as human $\alpha 7$ and $\alpha 9 \alpha 10$ nAChRs. Arg 30 and a 24-residues-long C-terminal tail were shown to be important for toxin binding. The toxin has a 24-long C-terminus tail, the truncation of which abolishes the activity of the toxin on $\alpha 9 \alpha 10$ nAChRs [118]. The toxin has a highly divergent structure within the second finger, where three of eight highly conserved in long-chain NTX residues, important for receptor interaction, are altered. Despite the lack of conserved residues within the second finger, the toxin retains properties of the long-chain three-finger $\alpha$-NTXs, and causes irreversible postsynaptic neurotoxicity at a nanomolar concentration $\left(\mathrm{IC}_{50}\right.$ on chick biventer cervices muscle preparation is $38.7 \mathrm{nM}$ ). Despite the sequence difference, the toxin retains the target specificity of the long-chain $\alpha$-NTXs, suggesting functional rather than structural similarity between the long-chain toxins

\subsection{Short-Chain Three-Finger $\alpha$-Neurotoxins}

Erabutoxin a and $\mathrm{b}$ are 62 amino-acid-long short-chain neurotoxins isolated from the Chinese sea snake Laticauda semifasciata with four disulfide bonds. The toxins are potent inhibitors of the muscle-type receptor, Torpedo receptor, and is a typical curarimetic toxin [119]. The toxin is a weak antagonist of homomeric neuronal $\alpha 7 \mathrm{nAChRs}$. Mutagenesis studies revealed a contribution of the conserved core residues within finger II, such as Lys 27, Trp 29, Asp 31, Phe 32, and Arg 33 for receptor binding [120,121]. In addition, His 6, Gln 7, Ser 8, and Gln 10 of finger I, as well as additional residues of finger II, such as Tyr 25, Gly 34, Ile 36, and Clu 38, are important for receptor binding.

$\mathrm{NmmI}$ is a 62 amino-acid long short-chain neurotoxin isolated from Naja mosambica possessing high affinity towards muscle-type $\mathrm{nAChR}$. The neurotoxin is capable of distinguishing $\alpha-\gamma$ and $\alpha-\delta$ subunit interfaces from an $\alpha-\varepsilon$ interface; it has an affinity 3 orders of magnitude higher towards the former compared to the latter [122,123]. Mutational studies revealed the significance of Lys 27 for toxin binding, and double-mutant cycle analysis revealed the interaction between Lys 27 and Glu 176 on $\gamma$ subunit [123].

\subsection{Dimeric Toxins}

Dimeric toxins demonstrate changes in target specificity compared to a monomeric form, with many dimeric toxins targeting neuronal types of nAChRs. Fulditoxin, haditoxin, dimeric $\alpha$-cobratoxin, $\mathrm{k}$-bungarotoxin, and irditoxin are examples of dimeric toxins. Fulditoxin is a homodimer of two short-chain three finger $\alpha-\mathrm{NT}$, with monomers linked together through 29 hydrophobic interactions between residues within Finger II of the monomer [102]. Haditoxin is a homodimer of two short-chain $\alpha$-3FNTX, with monomers bound to each other through 14 hydrogen bonds between finger III residues [124]. $\alpha$ - 
cobratoxin dimer contains two covalently joined monomers bound by two disulfide bonds [100,101]. K-bungarotoxin is a dimeric NTX, where two identical monomers are bound through 9 hydrogen bonds [100]. The dimeric nature of the toxin changes its binding properties, making the toxin lose its potency on muscle receptors while enabling its interaction with neuronal types of receptors ( $\alpha 3 \beta 2, \alpha 7$, and $\alpha 4 \beta 2 \mathrm{nAChRs})$. Irditoxin is a heterodimeric toxin with two protomers covalently bound by a disulfide bond. The toxin demonstrates specific activity on avian muscle receptors, with a 1000-times higher activity on avian receptors compared to rodent receptors (10 nM vs. $>10 \mu \mathrm{M} \mathrm{IC}{ }_{50}$ ) [103] (Table 2).

Table 2. Toxins of snake origin targeting nAChRs.

\begin{tabular}{|c|c|c|c|}
\hline Toxin Same (UniProt) & Snake Species & Target $\left(\mathrm{IC}_{50}\right.$ or $\mathrm{Kd}$ Values) & Ref. \\
\hline $\begin{array}{c}\alpha \text {-bungarotoxin } \\
\text { (P60615) }\end{array}$ & $\begin{array}{c}\text { Multibanded krait } \\
\text { Bungarus multicinctus } \\
\text { (Elapidae) }\end{array}$ & $\begin{array}{c}\text { Torpedo } \mathrm{nAChRs}\left(\mathrm{IC}_{50}=0.4 \mathrm{nM}\right) \\
\mathrm{h} \alpha 7\left(\mathrm{IC}_{50}=0.4 \mathrm{nM}\right) \\
\alpha 7-5 \mathrm{HT} 3 \text { chimera }\left(\mathrm{IC}_{50}=0.95 \mathrm{nM}\right)\end{array}$ & [119] \\
\hline $\begin{array}{l}\alpha \text {-cobratoxin } \\
\quad(\mathrm{P} 01391)\end{array}$ & $\begin{array}{l}\text { Indo-Chinese spitting cobra } \\
\text { Naja naja siamensis } \\
\text { (Elapidae) }\end{array}$ & $\begin{array}{c}\text { Ac-AChBP }\left(\mathrm{IC}_{50}=191 \mathrm{nM}\right) \\
\text { Ls-AChBP }\left(\mathrm{IC}_{50}=3.2 \mathrm{nM}\right) \\
\alpha 7\left(\mathrm{IC}_{50}=0.3 \mathrm{nM}\right) \\
\alpha 7-5 \mathrm{HT} 3 \text { chimera }\left(\mathrm{IC}_{50}=9 \mathrm{nM}\right)\end{array}$ & {$[119,125]$} \\
\hline$\alpha \delta$-bungarotoxin-1 & $\begin{array}{l}\text { Blue krait } \\
\text { Bungarus candidus } \\
\text { (Elapidae) }\end{array}$ & $\begin{array}{c}\text { T.californica } \mathrm{nAChRs}\left(\mathrm{IC}_{50}=11.4 \mathrm{nM}\right) \\
\mathrm{h} \alpha 7\left(\mathrm{IC}_{50}=1.18 \mathrm{nM}\right) \\
\mathrm{m} \alpha 1 \beta 1 \delta \varepsilon\left(\mathrm{IC}_{50}=15.7 \mathrm{nM}\right) \\
\mathrm{m} \alpha 1 \beta 1 \delta \gamma\left(\mathrm{IC}_{50}=2.54 \mathrm{nM}\right) \\
\text { (high affinity site } \alpha-\delta \\
0.0212 \mathrm{nM} \text { on } \alpha 1 \beta 1 \delta \varepsilon \\
0.115 \mathrm{nM} \text { on } \alpha 1 \beta 1 \delta \gamma \\
\text { low affinity sites } \\
\alpha-\varepsilon=20.3 \mathrm{nM} \\
\alpha-\gamma=21.8 \mathrm{nM})\end{array}$ & [117] \\
\hline $\begin{array}{l}\text { Drysdalin } \\
\text { (F8J2B3) }\end{array}$ & $\begin{array}{l}\text { White-lipped snake } \\
\text { Drysdalia coronoides } \\
\text { (Elapidae) }\end{array}$ & $\begin{array}{c}\text { rodent } \alpha 1 \beta 1 \delta \varepsilon\left(\mathrm{IC}_{50}=16.9 \mathrm{nM}\right) \\
\mathrm{h} \alpha 7\left(\mathrm{IC}_{50}=10 \mathrm{nM}\right) \\
\mathrm{h} \alpha 9 \propto 10\left(\mathrm{IC}_{50}=11.3 \mathrm{nM}\right)\end{array}$ & {$[118,126]$} \\
\hline $\begin{array}{l}\text { Erabutoxin -a } \\
\quad \text { (P60775) } \\
\text { Erabutoxin-b } \\
\text { (Q90VW1) }\end{array}$ & $\begin{array}{l}\text { Chinese sea snake } \\
\text { Laticauda semifasciata } \\
\text { (Elapidae) }\end{array}$ & $\begin{array}{c}\text { Torpedo } \mathrm{nAChR}(\mathrm{Kd}=0.07 \mathrm{nM}) \\
\alpha 7\left(\mathrm{IC}_{50}=0.5 \mu\right) \\
\alpha 7-5 \mathrm{HT} 3 \text { chimera: } \\
\text { Erabutoxin a }\left(\mathrm{IC}_{50}=21 \mathrm{nM}\right) \\
\text { Erabutoxin b }\left(\mathrm{IC}_{50}=22 \mathrm{nM}\right)\end{array}$ & {$[120,121,127]$} \\
\hline NmmI & $\begin{array}{l}\text { Mozambique spitting cobra } \\
\text { Naja mossambica } \\
\text { (Elapidae) }\end{array}$ & $\begin{array}{c}\alpha 1-\gamma \text { and } \alpha 1-\delta \text { interfaces }(\mathrm{Kd}=100 \mathrm{pM}) \\
\alpha 1-\varepsilon \text { interface }(\mathrm{Kd}=100 \mathrm{nM})\end{array}$ & {$[122,123]$} \\
\hline $\begin{array}{l}\text { א-Bungarotoxin } \\
\text { homodimer } \\
\text { (P01398) }\end{array}$ & $\begin{array}{l}\text { Multibanded krait } \\
\text { Bungarus multicinctus } \\
\text { (Elapidae) }\end{array}$ & $\begin{array}{c}\alpha 3 \beta 2\left(\mathrm{IC}_{50}=3 \mathrm{nM}\right) \\
\alpha 7 \text { and } \alpha 4 \beta 2 \text {-weak inhibition }\end{array}$ & {$[128,129]$} \\
\hline$\alpha$-cobratoxin homodimer & $\begin{array}{l}\text { Monocled cobra } \\
\text { Naja kaouthia } \\
\text { (Elapidae) }\end{array}$ & $\begin{array}{c}\alpha 1 \beta 1 \delta \gamma \text { of Torpedo }\left(\mathrm{IC}_{50}=10 \mathrm{nM}\right) \\
\alpha 7\left(\mathrm{IC}_{50}=0.2 \mu \mathrm{M}\right) \\
\alpha 3 \beta 2\left(\mathrm{IC}_{50}=0.15 \mu \mathrm{M}\right)\end{array}$ & {$[100,101]$} \\
\hline $\begin{array}{l}\text { Haditoxin } \\
(\mathrm{A} 8 \mathrm{~N} 286)\end{array}$ & $\begin{array}{l}\text { King cobra } \\
\text { Ophiophagus hannah } \\
\text { (Elapidae) }\end{array}$ & $\begin{array}{c}\alpha 7\left(\mathrm{IC}_{50}=0.2 \mu \mathrm{M}\right) \\
\alpha 1 \beta 1 \delta \gamma\left(\mathrm{IC}_{50}=0.5 \mu \mathrm{M}\right) \\
\alpha 3 \beta 2\left(\mathrm{IC}_{50}=0.5 \mu \mathrm{M}\right) \\
\alpha 4 \beta 2\left(\mathrm{IC}_{50}=2.6 \mu \mathrm{M}\right)\end{array}$ & [124] \\
\hline Fulditoxin & $\begin{array}{l}\text { Eastern coral snake } \\
\text { Micrurus fulvius fulvius } \\
\text { (Elapidae) }\end{array}$ & $\begin{array}{c}\mathrm{r} \alpha \beta \delta \varepsilon\left(\mathrm{IC}_{50}=2.6 \mu \mathrm{M}\right) \\
\mathrm{h} \alpha 4 \beta 2\left(\mathrm{IC}_{50}=1.8 \mu \mathrm{M}\right) \\
\mathrm{h} \alpha 7\left(\mathrm{IC}_{50}=7 \mu \mathrm{M}\right) \\
\text { h } \alpha 3 \beta 2\left(\mathrm{IC}_{50}=12.6 \mu \mathrm{M}\right) \\
\text { reversible blockade }\end{array}$ & [102] \\
\hline $\begin{array}{l}\text { Irditoxin A and B } \\
\text { (A0S864, A0S865) }\end{array}$ & $\begin{array}{l}\text { Brown tree snake } \\
\text { Boiga irregularis } \\
\text { (Colubridae) }\end{array}$ & $\begin{array}{c}\text { Species specific activity: } \\
\text { avian } \alpha 1 \beta 1 \delta \gamma\left(\mathrm{IC}_{50}=10 \mathrm{nM}\right) \\
\text { rodent } \alpha 1 \beta 1 \delta \gamma\left(\mathrm{IC}_{50}>10 \mu \mathrm{M}\right)\end{array}$ & [103] \\
\hline $\begin{array}{l}\text { Candoxin } \\
(\text { P81783) }\end{array}$ & $\begin{array}{l}\text { Malayan krait } \\
\text { Bungarus candidus } \\
\quad \text { (Elapidae) }\end{array}$ & $\begin{array}{c}\mathrm{r} \alpha 1 \beta 1 \delta \gamma \mathrm{nAChRs} \\
\left(\mathrm{IC}_{50}=10 \mathrm{nM}\right), \text { reversible block } \\
\mathrm{r} \alpha 7 \mathrm{nAChRs} \\
\left(\mathrm{IC}_{50}=50 \mathrm{nM}\right), \text { irreversible block }\end{array}$ & {$[97,99]$} \\
\hline $\begin{array}{l}\text { Weak toxin (WTX) } \\
\quad(\text { P82935) }\end{array}$ & $\begin{array}{l}\text { Monocled cobra } \\
\text { Naja kaouthia } \\
\text { (Elapidae) }\end{array}$ & $\begin{array}{l}\text { Torpedo } \mathrm{nAChR}(\mathrm{Kd}=90 \mathrm{nM}) \text { (native toxin) } \\
\mathrm{h} \alpha 7\left(\mathrm{IC}_{50}=14.8 \mu \mathrm{M}\right)(\text { recombinant }) \\
\text { T.californica }\left(\mathrm{IC}_{50}=3 \mu \mathrm{M}\right) \text { (recombinant) }\end{array}$ & {$[98,130,131]$} \\
\hline $\begin{array}{l}\text { Denmotoxin } \\
\text { (Q06ZW0) }\end{array}$ & $\begin{array}{l}\text { Mangrove snake } \\
\text { Boiga dendrophila } \\
\quad \text { (Colubridae) }\end{array}$ & $\begin{array}{l}\text { Bird specific postsynaptic activity-irreversible inhibition at chick } \\
\text { biventer neuromuscular preparation at } 10 \mu \mathrm{g} / \mathrm{mL} \\
\left(\mathrm{IC}_{50} \sim 300 \mathrm{nM}\right)\end{array}$ & [132] \\
\hline
\end{tabular}


Table 2. Cont.

\begin{tabular}{|c|c|c|c|}
\hline Toxin Same (UniProt) & Snake Species & Target ( $\mathrm{IC}_{50}$ or Kd Values) & Ref. \\
\hline $\begin{array}{c}\text { Lc-a } \\
(\text { P0C8R7) } \\
\text { Lc-b } \\
\text { (P0C8R8) }\end{array}$ & $\begin{array}{l}\text { Yellow-lipped sea krait } \\
\text { Laticauda colubrina } \\
\quad \text { (Elapidae) }\end{array}$ & $\begin{array}{c}\text { Muscle } \mathrm{nAChR} \\
\mathrm{LD} 50=0.12 \mu / \mathrm{g} \text { following intramuscular injection in mice }\end{array}$ & [133] \\
\hline $\begin{array}{l}\text { Neurotoxin Oh-9 } \\
\quad(\text { P83302) }\end{array}$ & $\begin{array}{l}\text { King cobra } \\
\text { Ophiophagus hannah } \\
\text { (Elapidae) }\end{array}$ & $\begin{array}{c}\mathrm{IC}_{50} \text { on carbachol-induced chicken cervicis muscle contraction-88 nM; } \\
\text { Rat adult muscle }\left(\mathrm{IC}_{50}=3.1 \mu \mathrm{M}\right) \\
\text { Rat fetal muscle }\left(\mathrm{IC}_{50}=5.6 \mu \mathrm{M}\right)\end{array}$ & {$[134,135]$} \\
\hline $\begin{array}{l}\text { Waglerin-1 } \\
\text { (P24335) }\end{array}$ & $\begin{array}{l}\text { Wagler's palm viper } \\
\text { Trimeresurus wagleri } \\
\quad \text { (Viperidae) }\end{array}$ & $\begin{array}{c}\mathrm{m} \alpha 1 \beta 1 \delta \varepsilon\left(\mathrm{IC}_{50}=50 \mathrm{nM} \text {, end-plate potential inhibition }\right) \\
\mathrm{m} \alpha 1 \beta 1 \delta \gamma(\mathrm{IC} 50=36 \mu \mathrm{M}) \\
2000 \text {-fold higher affinity to the } \alpha-\varepsilon(\mathrm{Kd}=9.8 \mathrm{nM}) \text { than to the } \alpha-\delta \\
(\mathrm{Kd}=20.2 \mu \mathrm{M}) \text { binding site interface of the mouse muscle receptor; } \\
\mathrm{h} \alpha 1 \beta 1 \delta \varepsilon \\
(\mathrm{Kd} 1=692 \mathrm{nM}, \mathrm{Kd} 2=200 \mu \mathrm{M}) \\
\operatorname{r} \alpha 1 \beta 1 \delta \varepsilon \\
(\mathrm{Kd} 1=1.1 \mu \mathrm{M}, \mathrm{Kd} 2=36 \mu \mathrm{M})\end{array}$ & [136-138] \\
\hline
\end{tabular}

\subsection{Non-Conventional Toxins}

Weak toxin (WTX) isolated from cobra Naja kaouthia is a 65 amino-acid-long toxin with five disulfide bonds. By length, it is similar to short-chain toxins; by number of disulfide bonds, it is similar to long-chain toxins. However, unlike in long-chain neurotoxins, the fifth bond is within the first finger. The toxin is named "weak" because of its low toxicity. It was reported that, at $2 \mathrm{mg} / \mathrm{kg}$ delivered intravenously, it was not toxic on rats [98]. The toxin inhibits Torpedo nAChR with a Kd of $90 \mathrm{nM}$, and it also shows affinity towards neuronal $\alpha 7$ and muscarinic receptors present within adrenal medulla cells [130]. Arg 31 and Arg 32, both within the second finger, are important for the interaction with muscle and $\alpha 7 \mathrm{nAChRs} \mathrm{[131].} \mathrm{The} \mathrm{same} \mathrm{residues,} \mathrm{together} \mathrm{with} \mathrm{Arg} \mathrm{37,} \mathrm{are} \mathrm{crucial} \mathrm{for} \mathrm{binding} \mathrm{to}$ human muscarinic M1 and M3 receptors [139].

Candoxin is a 66-amino-acid-long toxin isolated from Bungarus candidus snake, similar in length to short-chain toxins. However, unlike short-chain toxins, it has five disulfide bonds. The location of the fifth bond is within finger I, which is similar to WTX $[97,99]$. Candoxin blocks muscle and neuronal $\alpha 7 \mathrm{nAChR}$. IC $\mathrm{C}_{50}$ on rat $\alpha 1 \beta 1 \delta \gamma$ expressed in oocytes is $10 \mathrm{nM}$, on rat $\alpha 7$ is $50 \mathrm{nM}$. The inhibition by candoxin is reversible for muscle-type of receptors, and poorly reversible for $\alpha 7 \mathrm{nAChR}$. $\mathrm{LD}_{50}$ of candoxin is $0.83 \mathrm{mg} / \mathrm{kg}$, which is higher than of WTX [97].

\subsection{Toxins with Unique Structure}

Denmotoxin is a 77-amino-acid-long toxin isolated from Boiga dendrophila snake, with a unique property to discriminate between its targets. It irreversibly blocks chick $\alpha \beta \delta \gamma$ $\mathrm{nAChR}$, while it is a 100-fold weaker antagonist of mouse muscle nAChR [132]. Injected intraperitoneally to mice at $20 \mathrm{mg} / \mathrm{kg}$, no biological effect was observed. Structurally, it possesses five disulfide bonds, with an extra disulfide bond within loop I of the toxin.

Lc-a and Lc-b are both 69 amino-acid-long toxins isolated from sea snake Laticauda colubrina [133]. They both contain four disulfide bonds and are lethal when injected intramuscularly to mice with an $\mathrm{LD}_{50}$ of $0.12 \mathrm{mg} / \mathrm{kg}$.

$\Omega$-Neurotoxin Oh-9 is a 57 amino-acid-long toxin isolated from Ophiophagus Hannah, with four disulfide bonds and a low sequence similarity with $\alpha$-neurotoxins of snake origin [134]. The toxin inhibits rat muscle $\alpha 1 \beta 1 \varepsilon \delta$ nAChRs, as well as $\alpha 3 \beta 2$ receptor subtype. Mutagenesis studies revealed that the tip of loop II is not crucial for binding. Met 25 and Phe 27 constitute the binding core of the toxin to both muscle and neuronal receptor types, whereas Thr 23 and Phe 26 are critical for interaction with $\alpha 1 \beta 1 \varepsilon \delta$ but not with $\alpha 3 \beta 2$ [135].

$\alpha \delta$-bungarotoxin- 1 is 73 amino-acid-long toxin isolated from Bungarus candidus, with five disulfide bonds and inhibitory activity on muscle and neuronal $\alpha 7 \mathrm{nAChRs}$. Unlike $\alpha$-Bgtx $\alpha \delta$-Bgtx binds to the target receptor in a reversible manner. Binding affinities are higher at the $\alpha-\delta$ interface than at the $\alpha-\gamma$ or $\alpha-\varepsilon$ interfaces [117]. The reason for such selectivity could be due to a shorter finger I, and thus a smaller number of contacts with 
the receptor interface, as well fewer positively charged amino acids within finger II of the toxin.

Waglerin-1 is 22 amino-acid-long peptide with a single disulfide bond. Despite its difference in length and structural features with other snake neurotoxins, Waglerin-1 blocks the muscle $\mathrm{nAChR}$ containing $\varepsilon$ subunit $[136,140]$, and has a 2000-fold higher affinity for $\alpha-\varepsilon$ compared to the $\alpha-\delta$ subunit interface. The toxin is not potent on the fetal muscle receptor containing the $\gamma$ subunit [136]. Besides its activity on nAChRs, Waglerin- 1 also potentiates and suppresses $\mathrm{GABA}_{\mathrm{A}}$ receptors $\left(\mathrm{EC}_{50}=24 \mu \mathrm{M}\right)$ [137].

\section{Peptides of Spider Venom Origin as Potential Ligands Acting on nAChRs}

Spiders do not possess a diverse arsenal of toxins which act on acetylcholine receptors. This fact is surprising when considering the importance of acetylcholine receptors for insects, the main prey of spiders. The action of spider toxins on nicotinic receptors is observed, alongside their activity on other targets.

The toxin HWTX-1 (Huwentoxin-1), from a Chinese bird spider Selenocosmia huwena (synonymous to Haplopelma schmidti) [141,142], is a 33 amino-acid-long peptide with six cysteines connected in a following way: $\mathrm{C} 1-\mathrm{C} 4 ; \mathrm{C} 2-\mathrm{C} 5$; $\mathrm{C} 3-\mathrm{C} 6$, which is similar to disulfide bonds of $\omega$-conotoxin GVIA. HWTX-1 was initially shown to be potent in inhibiting neuromuscular transmission and evoking muscle paralysis. At $10 \mathrm{ug} / \mathrm{mL}$, the blockade of twitch response was achieved in $15.2 \mathrm{~min}$ in a mouse phrenic nerve-hemidiagraphm preparation [142]. Later, however, the effect of the toxin on acetylcholine receptors was questioned [143-145]. Now, it is established that the main target of the HWTX-I is the $\mathrm{N}$-type Calcium channel ( $\mathrm{IC}_{50}$ is $\left.100 \mathrm{nM}\right)$ [144].

Another toxin of spider origin with potential activity on nicotinic acetylcholine receptors is $\omega$-Agatoxin IVA, derived from the American funnel spider, Agelenopsis aperta. The inhibitory activity of the toxin was demonstrated on bovine chromaffin cells, where the toxin at a $100 \mathrm{nM}$ concentration inhibited nicotine-evoked current [146]. However, besides this, the toxin was not shown to be active on nicotinic receptors. The main mechanism of its action is through the blockage of P-type voltage-gated calcium channels [147,148].

The only peptidic toxin of spider origin that was shown to affect nicotinic receptors is к-Hexatoxin Hv1c (к-HXTX-Hv1C), from the blue-mountain funnel web spider, Hadronyche versuta [149]. It acts as a positive allosteric modulator of the receptors (Table 3).

Table 3. The toxins of spider origin, with a suggested and demonstrated activity on nAChRs.

\begin{tabular}{ccc}
\hline Toxin Name/Spider Species/UniProt & Amino-Acid Sequence & Ref. \\
\hline HWTX-I & ACKGVFDACTPGKNECCPNRVCSDKHKWCKWKL \\
Selenocosmia huwena & & \\
P56676 & KKKCIAKDYGRCKWGGTPCCRGRGCCSIMGTNCECPRLIMEGLGLA & [146] \\
\hline A-agatoxin IVA & & \\
Agenelopsis aperta & & \\
P30288 & AICTGADRPCAACCPCCPGTSCKAESNGVSYCRKDEP & \\
K-HXTX-Hv1c & & \\
\hline P82228 & & \\
\hline
\end{tabular}

\section{Peptides of Scorpion Venom Origin as Potential Ligands Acting on nAChRs}

Scorpion venom is a rich source of ligands targeting voltage-gated potassium $(\mathrm{Kv})$ and sodium (Nav) channels [150,151]. The affinity for these channels is at $\mathrm{nM}$ and even at $\mathrm{pM}$ range. Scorpion toxins are classified into several families and subfamilies based on four criteria. The criteria include the type of affected ion channel (sodium, potassium, calcium, or chloride) [152], target site on the channel, three-dimensional structure, and type of response. The Nav-targeting toxins are divided into $\alpha$ - and $\beta$-type depending on the binding site on the channels and the resultant effect of binding. $\alpha$-toxins bind at site 3 and 
inhibit channel inactivation, while $\beta$ - toxins bind at site 4 and change channel activation. The $\mathrm{Kv}$-targeting toxins are divided into $\alpha_{-}, \beta-, \gamma_{-}$, and $\kappa_{-}$-families. $\kappa_{-}$family toxins have $\alpha$-helix-loop-helix fold, where two short $\alpha$-helices are connected by a $\beta$-turn [152].

A recent report by Kasheverov [153] showed that scorpion peptides demonstrate target promiscuity (Table 4). Thus, scorpion toxins within $\alpha$-KTx and $\kappa-K T X$ families target nicotinic AChRs of muscle and $\alpha 7$ type, with a higher affinity towards muscle-type receptor vs. homomeric neuronal $\alpha 7$ type. For example, the IC50 of HelaTx1 on Torpedo californica nAChRs is $1.4 \pm 0.1 \mu \mathrm{M}$; on human, $\alpha 7 \mathrm{nAChR}$ is $64 \pm 7 \mu \mathrm{M}$ (Table 4 ). HelaTx 1 is a toxin within the $\kappa-K T x$ family with two short $\alpha$-helices stabilized by two disulfide bonds; by structure, it resembles $\alpha$-conotoxins. Surprisingly, it has a higher affinity towards muscle-type nAChRs compared to the Kv channel. Overall, affinities towards the nAChRs for scorpion toxins are in $\mu \mathrm{M}$ range, which makes it unlikely that $\mathrm{nAChRs}$ are the main biological targets for scorpion venom.

Table 4. The amino-acid sequence and potencies of scorpion toxins targeting nAChRs.

\begin{tabular}{|c|c|c|c|c|}
\hline Toxin Name/Species & Structure & & $\mathrm{IC}_{50}$ & Ref. \\
\hline $\begin{array}{l}\text { OSK-1 ( } \alpha \text {-KTx family)/Orthochirus } \\
\text { scrobiculosus }\end{array}$ & GVIINVKCKISRQCLEPCKKAGMRFGKCMNGKCHCTPK & $\begin{array}{l}\text { (a) } \\
\text { (b) } \\
\text { (c) }\end{array}$ & $\begin{array}{l}1.6 \mu \mathrm{M}-\text { mouse muscle; } \\
0.505 \pm 0.040 \mu \mathrm{M}-\text { Torpedo californica; } \\
20 \mu \mathrm{M}-\mathrm{h} \alpha 7\end{array}$ & {$[153,154]$} \\
\hline $\begin{array}{c}\text { HelaTx1 ( } \mathrm{\kappa}-\mathrm{KTx} \\
\text { family)/Heterometrus laoticus }\end{array}$ & SCKKECSGSRRTKKCMOKCNREHGH & $\begin{array}{l}\text { (a) } \\
\text { (b) }\end{array}$ & $\begin{array}{l}1.4 \pm 0.1 \mu \mathrm{M}-\text { Torpedo californica } \\
64 \pm 7 \mu \mathrm{M}-\mathrm{h} \alpha 7\end{array}$ & [153] \\
\hline Spinoxin/Heterometrus spinifer & IRCSGSRDCYSPCMKQTGCPNAKCINKSCKCYGC & $\begin{array}{l}\text { (a) } \\
\text { (b) }\end{array}$ & $\begin{array}{l}0.490 \pm 0.030 \mu \mathrm{M}-\text { Torpedo californica; } \\
\gg 20 \mu \mathrm{M}-\mathrm{h} \alpha 7\end{array}$ & [153] \\
\hline
\end{tabular}

\section{Conclusions}

Natural products provide a rich source of ligands targeting $\mathrm{nAChRs.} \mathrm{The} \mathrm{venom}$ of snakes and Cone snails is especially rich in toxins that have a high affinity (nM range) and selectivity towards nAChRs. For example, $\alpha$-conotoxins with $3 / 5$ spacing between disulfide bridges, as well as long-chain three-finger $\alpha$-neurotoxins of snake origin, are potent inhibitors of muscle-type nAChRs. But $\alpha$-conotoxins with $4 / 7$ spacing that target neuronal types of $\mathrm{nAChR}$ often demonstrate similarly high affinities towards multiple kinds of heteromeric receptors. The selectivity of toxins targeting multiple types of receptors could be improved, however. $\alpha$-conotoxin MII [H9A; L15A], for example, demonstrates selectivity towards $\alpha 6$-containing receptors; ArIB [V11L; V16D] is a selective $\alpha 7 \mathrm{nAChR}$ antagonist, while PeIA [S9H; V10A; E14N] can discriminate between $\beta 2$ and $\beta 4$ receptor subunits in $\alpha 6$-containing receptors. Novel toxins of venomous origin hold great potential for the development of highly potent and selective ligand targeting $\mathrm{nAChRs}$, and they could be extensively used in research.

Funding: This research was funded by Nazarbayev University (NU) Faculty Development Competitive Research Grant, grant number 110119FD4517.

Institutional Review Board Statement: Not applicable.

Informed Consent Statement: Not applicable.

Acknowledgments: The authors would like to acknowledge Yunona Bukasova for assistance with Figure 1 and proofreading the manuscript.

Conflicts of Interest: The authors declare no conflict of interest.

\section{References}

1. Albuquerque, E.X.; Pereira, E.F.R.; Alkondon, M.; Rogers, S.W. Mammalian Nicotinic Acetylcholine Receptors: From Structure to Function. Physiol. Rev. 2009, 89, 73-120. [CrossRef] [PubMed]

2. Changeux, J.-P. Discovery of the First Neurotransmitter Receptor: The Acetylcholine Nicotinic Receptor. Biomolecules 2020, $10,547$. [CrossRef]

3. Millar, N.S.; Gotti, C. Diversity of Vertebrate Nicotinic Acetylcholine Receptors. Neuropharmacology 2009, 56, 237-246. [CrossRef] 
4. Scholze, P.; Huck, S. The A5 Nicotinic Acetylcholine Receptor Subunit Differentially Modulates A $4 \beta 2^{*}$ and A3 $\beta 4^{*}$ Receptors. Front. Synaptic Neurosci. 2020, 12, 54. [CrossRef]

5. Boorman, J.P.; Beato, M.; Groot-Kormelink, P.J.; Broadbent, S.D.; Sivilotti, L.G. The Effects of B3 Subunit Incorporation on the Pharmacology and Single Channel Properties of Oocyte-Expressed Human A3ß4 Neuronal Nicotinic Receptors. J. Biol. Chem. 2003, 278, 44033-44040. [CrossRef]

6. Murray, T.A.; Bertrand, D.; Papke, R.L.; George, A.A.; Pantoja, R.; Srinivasan, R.; Liu, Q.; Wu, J.; Whiteaker, P.; Lester, H.A.; et al. A7 $\beta 2$ Nicotinic Acetylcholine Receptors Assemble, Function, and Are Activated Primarily via Their A7-A7 Interfaces. Mol. Pharmacol. 2012, 81, 175. [CrossRef] [PubMed]

7. Plazas, P.V.; Katz, E.; Gomez-Casati, M.E.; Bouzat, C.; Elgoyhen, A.B. Stoichiometry of the A9 $\alpha 10$ Nicotinic Cholinergic Receptor J. Neurosci. 2005, 25, 10905. [CrossRef] [PubMed]

8. Gharpure, A.; Noviello, C.M.; Hibbs, R.E. Progress in Nicotinic Receptor Structural Biology. Neuropharmacology 2020, $171,108086$. [CrossRef] [PubMed]

9. Karlin, A. A Touching Picture of Nicotinic Binding. Neuron 2004, 41, 841-842. [CrossRef]

10. Kumbhare, D.; Palys, V.; Toms, J.; Wickramasinghe, C.S.; Amarasinghe, K.; Manic, M.; Hughes, E.; Holloway, K.L. Nucleus Basalis of Meynert Stimulation for Dementia: Theoretical and Technical Considerations. Front. Neurosci. 2018, 12, 614. [CrossRef] [PubMed]

11. Govind, A.P.; Vezina, P.; Green, W.N. Nicotine-Induced Upregulation of Nicotinic Receptors: Underlying Mechanisms and Relevance to Nicotine Addiction. Biochem. Pharmacol. 2009, 78, 756-765. [CrossRef] [PubMed]

12. Carbone, A.-L.; Moroni, M.; Groot-Kormelink, P.-J.; Bermudez, I. Pentameric Concatenated (A4)2(B2)3 and (A4)3(B2)2 Nicotinic Acetylcholine Receptors: Subunit Arrangement Determines Functional Expression. Br. J. Pharmacol. 2009, 156, 970-981. [CrossRef] [PubMed]

13. McGranahan, T.M.; Patzlaff, N.E.; Grady, S.R.; Heinemann, S.F.; Booker, T.K. A4 $\beta 2$ Nicotinic Acetylcholine Receptors on Dopaminergic Neurons Mediate Nicotine Reward and Anxiety Relief. J. Neurosci. 2011, 31, 10891. [CrossRef] [PubMed]

14. McIntosh, J.M.; Absalom, N.; Chebib, M.; Elgoyhen, A.B.; Vincler, M. Alpha9 Nicotinic Acetylcholine Receptors and the Treatment of Pain. Biochem. Pharmacol. 2009, 78, 693-702. [CrossRef]

15. Del Bufalo, A.; Cesario, A.; Salinaro, G.; Fini, M.; Russo, P. Alpha9 Alpha10 Nicotinic Acetylcholine Receptors as Target for the Treatment of Chronic Pain. Curr. Pharm. Des. 2014, 20, 6042-6047. [CrossRef]

16. Hone, A.J.; McIntosh, J.M. Nicotinic Acetylcholine Receptors in Neuropathic and Inflammatory Pain. FEBS Lett. 2018, 592, 1045-1062. [CrossRef]

17. Bencherif, M.; Lippiello, P.M.; Lucas, R.; Marrero, M.B. Alpha7 Nicotinic Receptors as Novel Therapeutic Targets for InflammationBased Diseases. Cell. Mol. Life Sci. 2011, 68, 931-949. [CrossRef]

18. Winek, K.; Soreq, H.; Meisel, A. Regulators of Cholinergic Signaling in Disorders of the Central Nervous System. J. Neurochem. 2021. [CrossRef]

19. Dineley, K.T.; Pandya, A.A.; Yakel, J.L. Nicotinic ACh Receptors as Therapeutic Targets in CNS Disorders. Trends Pharmacol. Sci. 2015, 36, 96-108. [CrossRef] [PubMed]

20. Quik, M.; Zhang, D.; McGregor, M.; Bordia, T. Alpha7 Nicotinic Receptors as Therapeutic Targets for Parkinson's Disease. Biochem. Pharmacol. 2015, 97, 399-407. [CrossRef]

21. Pennington, M.W.; Czerwinski, A.; Norton, R.S. Peptide Therapeutics from Venom: Current Status and Potential. Bioorgan. Med. Chem. 2018, 26, 2738-2758. [CrossRef] [PubMed]

22. Jin, A.-H.; Muttenthaler, M.; Dutertre, S.; Himaya, S.W.A.; Kaas, Q.; Craik, D.J.; Lewis, R.J.; Alewood, P.F. Conotoxins: Chemistry and Biology. Chem. Rev. 2019, 119, 11510-11549. [CrossRef] [PubMed]

23. Abraham, N.; Lewis, R.J. Neuronal Nicotinic Acetylcholine Receptor Modulators from Cone Snails. Mar. Drugs 2018, 16, 208. [CrossRef]

24. Giribaldi, J.; Dutertre, S. $\alpha$-Conotoxins to Explore the Molecular, Physiological and Pathophysiological Functions of Neuronal Nicotinic Acetylcholine Receptors. Neurosci. Lett. 2018, 679, 24-34. [CrossRef] [PubMed]

25. McIntosh, J.M.; Santos, A.D.; Olivera, B.M. Conus Peptides Targeted to Specific Nicotinic Acetylcholine Receptor Subtypes. Annu. Rev. Biochem. 1999, 68, 59-88. [CrossRef]

26. Jacobsen, R.B.; DelaCruz, R.G.; Grose, J.H.; McIntosh, J.M.; Yoshikami, D.; Olivera, B.M. Critical Residues Influence the Affinity and Selectivity of $\alpha$-Conotoxin MI for Nicotinic Acetylcholine Receptors. Biochemistry 1999, 38, 13310-13315. [CrossRef]

27. Liu, L.; Chew, G.; Hawrot, E.; Chi, C.; Wang, C. Two Potent A3/5 Conotoxins from Piscivorous Conus Achatinus. Acta Biochim. Biophys. Sin. 2007, 39, 438-444. [CrossRef]

28. Groebe, D.R.; Dumm, J.M.; Levitan, E.S.; Abramson, S.N. Alpha-Conotoxins Selectively Inhibit One of the Two Acetylcholine Binding Sites of Nicotinic Receptors. Mol. Pharmacol. 1995, 48, 105.

29. Groebe, D.R.; Gray, W.R.; Abramson, S.N. Determinants Involved in the Affinity of $\alpha$-Conotoxins GI and SI for the Muscle Subtype of Nicotinic Acetylcholine Receptors. Biochemistry 1997, 36, 6469-6474. [CrossRef]

30. Ning, J.; Li, R.; Ren, J.; Zhangsun, D.; Zhu, X.; Wu, Y.; Luo, S. Alanine-Scanning Mutagenesis of $\alpha$-Conotoxin GI Reveals the Residues Crucial for Activity at the Muscle Acetylcholine Receptor. Mar. Drugs 2018, 16, 507. [CrossRef] 
31. Giribaldi, J.; Wilson, D.; Nicke, A.; El Hamdaoui, Y.; Laconde, G.; Faucherre, A.; Moha Ou Maati, H.; Daly, N.L.; Enjalbal, C.; Dutertre, S. Synthesis, Structure and Biological Activity of CIA and CIB, Two $\alpha$-Conotoxins from the Predation-Evoked Venom of Conus Catus. Toxins 2018, 10, 222. [CrossRef]

32. Ramilo, C.A.; Zafaralla, G.C.; Nadasdi, L.; Hammerland, L.G.; Yoshikami, D.; Gray, W.R.; Kristipati, R.; Ramachandran, J.; Miljanich, G. Novel .Alpha.- and .Omega.-Conotoxins and Conus Striatus Venom. Biochemistry 1992, 31, 9919-9926. [CrossRef] [PubMed]

33. Quiram, P.A.; Sine, S.M. Structural Elements in $\alpha$-Conotoxin ImI Essential for Binding to Neuronal A7 Receptors. J. Biol. Chem. 1998, 273, 11007-11011. [CrossRef] [PubMed]

34. Ellison, M.; McIntosh, J.M.; Olivera, B.M. $\alpha$-Conotoxins ImI and ImII: Similar A7 nicotinic receptor antagonists act at different sites. J. Biol. Chem. 2003, 278, 757-764. [CrossRef]

35. Ellison, M.; Feng, Z.-P.; Park, A.J.; Zhang, X.; Olivera, B.M.; McIntosh, J.M.; Norton, R.S. $\alpha$-RgIA, a Novel Conotoxin That Blocks the A9 $\alpha 10$ NAChR: Structure and Identification of Key Receptor-Binding Residues. J. Mol. Biol. 2008, 377, 1216-1227. [CrossRef]

36. Chhabra, S.; Belgi, A.; Bartels, P.; van Lierop, B.J.; Robinson, S.D.; Kompella, S.N.; Hung, A.; Callaghan, B.P.; Adams, D.J.; Robinson, A.J.; et al. Dicarba Analogues of $\alpha$-Conotoxin RgIA. Structure, Stability, and Activity at Potential Pain Targets. J. Med. Chem. 2014, 57, 9933-9944. [CrossRef] [PubMed]

37. Azam, L.; Dowell, C.; Watkins, M.; Stitzel, J.A.; Olivera, B.M.; McIntosh, J.M. $\alpha$-Conotoxin BuIA, a Novel Peptide from Conus Bullatus, Distinguishes among Neuronal Nicotinic Acetylcholine Receptors. J. Biol. Chem. 2005, 280, 80-87. [CrossRef] [PubMed]

38. Kim, H.-W.; McIntosh, J.M. A6 NAChR Subunit Residues That Confer $\alpha$-Conotoxin BuIA Selectivity. FASEB J. 2012, 26, 4102-4110. [CrossRef]

39. Azam, L.; Maskos, U.; Changeux, J.-P.; Dowell, C.D.; Christensen, S.; De Biasi, M.; McIntosh, J.M. $\alpha$-Conotoxin BuIA[T5A;P6O]: A Novel Ligand That Discriminates between A6ß4 and A6ß2 Nicotinic Acetylcholine Receptors and Blocks Nicotine-Stimulated Norepinephrine Release. FASEB J. 2010, 24, 5113-5123. [CrossRef]

40. Quinton, L.; Servent, D.; Girard, E.; Molgó, J.; Le Caer, J.-P.; Malosse, C.; Haidar, E.A.; Lecoq, A.; Gilles, N.; Chamot-Rooke, J. Identification and Functional Characterization of a Novel $\alpha$-Conotoxin (EIIA) from Conus Ermineus. Anal. Bioanal. Chem. 2013, 405, 5341-5351. [CrossRef] [PubMed]

41. Grishin, A.A.; Cuny, H.; Hung, A.; Clark, R.J.; Brust, A.; Akondi, K.; Alewood, P.F.; Craik, D.J.; Adams, D.J. Identifying Key Amino Acid Residues That Affect $\alpha$-Conotoxin AuIB Inhibition of A3 $\beta 4$ Nicotinic Acetylcholine Receptors. J. Biol. Chem. 2013, 288, 34428-34442. [CrossRef]

42. Li, L.; Liu, N.; Ding, R.; Wang, S.; Liu, Z.; Li, H.; Zheng, X.; Dai, Q. A Novel 4/6-Type Alpha-Conotoxin ViIA Selectively Inhibits NAchR A3ß2 Subtype. Acta Biochim. Biophys. Sin. 2015, 47, 1023-1028. [CrossRef] [PubMed]

43. van Hout, M.; Valdes, A.; Christensen, S.B.; Tran, P.T.; Watkins, M.; Gajewiak, J.; Jensen, A.A.; Olivera, B.M.; McIntosh, J.M. $\alpha$-Conotoxin VnIB from Conus Ventricosus Is a Potent and Selective Antagonist of A6 $\beta 4^{*}$ Nicotinic Acetylcholine Receptors. Neuropharmacology 2019, 157, 107691. [CrossRef] [PubMed]

44. Wu, Y.; Zhangsun, D.; Zhu, X.; Kaas, Q.; Zhangsun, M.; Harvey, P.J.; Craik, D.J.; McIntosh, J.M.; Luo, S. $\alpha$-Conotoxin [S9A]TxID Potently Discriminates between A3 $\beta 4$ and A6/A3ß4 Nicotinic Acetylcholine Receptors. J. Med. Chem. 2017, 60, 5826-5833. [CrossRef] [PubMed]

45. Loughnan, M.L.; Nicke, A.; Jones, A.; Adams, D.J.; Alewood, P.F.; Lewis, R.J. Chemical and Functional Identification and Characterization of Novel Sulfated $\alpha$-Conotoxins from the Cone Snail Conus Anemone. J. Med. Chem. 2004, 47, 1234-1241. [CrossRef]

46. Whiteaker, P.; Christensen, S.; Yoshikami, D.; Dowell, C.; Watkins, M.; Gulyas, J.; Rivier, J.; Olivera, B.M.; McIntosh, J.M. Discovery, Synthesis, and Structure Activity of a Highly Selective A7 Nicotinic Acetylcholine Receptor Antagonist. Biochemistry 2007, 46, 6628-6638. [CrossRef]

47. Ning, J.; Ren, J.; Xiong, Y.; Wu, Y.; Zhangsun, M.; Zhangsun, D.; Zhu, X.; Luo, S. Identification of Crucial Residues in $\alpha$-Conotoxin EI Inhibiting Muscle Nicotinic Acetylcholine Receptor. Toxins 2019, 11, 603. [CrossRef]

48. Lin, B.; Xu, M.; Zhu, X.; Wu, Y.; Liu, X.; Zhangsun, D.; Hu, Y.; Xiang, S.-H.; Kasheverov, I.E.; Tsetlin, V.I.; et al. From Crystal Structure of $\alpha$-Conotoxin GIC in Complex with Ac-AChBP to Molecular Determinants of Its High Selectivity for A3 $\beta 2$ NAChR. Sci. Rep. 2016, 6, 22349. [CrossRef]

49. Banerjee, J.; Yongye, A.B.; Chang, Y.-P.; Gyanda, R.; Medina-Franco, J.L.; Armishaw, C.J. Design and Synthesis of $\alpha$-Conotoxin GID Analogues as Selective A4 32 Nicotinic Acetylcholine Receptor Antagonists. Biopolymers 2014, 102, 78-87. [CrossRef]

50. Lebbe, E.K.M.; Peigneur, S.; Maiti, M.; Devi, P.; Ravichandran, S.; Lescrinier, E.; Ulens, C.; Waelkens, E.; D'Souza, L.; Herdewijn, P.; et al. Structure-Function Elucidation of a New $\alpha$-Conotoxin, Lo1a, from Conus Longurionis. J. Biol. Chem. 2014, 289, 9573-9583. [CrossRef]

51. Inserra, M.C.; Kompella, S.N.; Vetter, I.; Brust, A.; Daly, N.L.; Cuny, H.; Craik, D.J.; Alewood, P.F.; Adams, D.J.; Lewis, R.J. Isolation and Characterization of $\alpha$-Conotoxin LsIA with Potent Activity at Nicotinic Acetylcholine Receptors. Biochem. Pharmacol. 2013, 86, 791-799. [CrossRef] [PubMed]

52. Chen, J.; Liang, L.; Ning, H.; Cai, F.; Liu, Z.; Zhang, L.; Zhou, L.; Dai, Q. Cloning, Synthesis and Functional Characterization of a Novel $\alpha$-Conotoxin Lt1.3. Mar. Drugs 2018, 16, 112. [CrossRef] 
53. Luo, S.; Zhangsun, D.; Schroeder, C.I.; Zhu, X.; Hu, Y.; Wu, Y.; Weltzin, M.M.; Eberhard, S.; Kaas, Q.; Craik, D.J.; et al. A Novel A4/7-Conotoxin LvIA from Conus Lividus That Selectively Blocks A3 $\beta 2$ vs. A6/A3 $\beta 2 \beta 3$ Nicotinic Acetylcholine Receptors. FASEB J. 2014, 28, 1842-1853. [CrossRef] [PubMed]

54. Xu, M.; Zhu, X.; Yu, J.; Yu, J.; Luo, S.; Wang, X. The Crystal Structure of Ac-AChBP in Complex with $\alpha$-Conotoxin LvIA Reveals the Mechanism of Its Selectivity towards Different NAChR Subtypes. Protein Cell 2017, 8, 675-685. [CrossRef] [PubMed]

55. Everhart, D.; Cartier, G.E.; Malhotra, A.; Gomes, A.V.; McIntosh, J.M.; Luetje, C.W. Determinants of Potency on Alpha-Conotoxin MII, a Peptide Antagonist of Neuronal Nicotinic Receptors. Biochemistry 2004, 43, 2732-2737. [CrossRef]

56. McIntosh, J.M.; Azam, L.; Staheli, S.; Dowell, C.; Lindstrom, J.M.; Kuryatov, A.; Garrett, J.E.; Marks, M.J.; Whiteaker, P. Analogs of Alpha-Conotoxin MII Are Selective for Alpha6-Containing Nicotinic Acetylcholine Receptors. Mol. Pharmacol. 2004, 65, 944-952. [CrossRef] [PubMed]

57. Wang, S.; Zhao, C.; Liu, Z.; Wang, X.; Liu, N.; Du, W.; Dai, Q. Structural and Functional Characterization of a Novel $\alpha$-Conotoxin

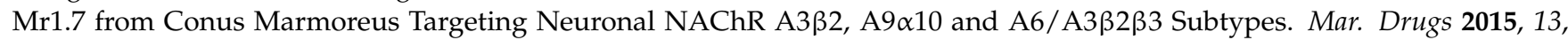
3259-3275. [CrossRef] [PubMed]

58. Hone, A.J.; Ruiz, M.; Scadden, M.; Christensen, S.; Gajewiak, J.; Azam, L.; McIntosh, J.M. Positional Scanning Mutagenesis of $\alpha$-Conotoxin PeIA Identifies Critical Residues That Confer Potency and Selectivity for A6/A3 $\beta 2 \beta 3$ and A3 $\beta 2$ Nicotinic Acetylcholine Receptors. J. Biol. Chem. 2013, 288, 25428-25439. [CrossRef]

59. Hone, A.J.; Fisher, F.; Christensen, S.; Gajewiak, J.; Larkin, D.; Whiteaker, P.; McIntosh, J.M. PeIA-5466: A Novel Peptide Antagonist Containing Non-Natural Amino Acids That Selectively Targets A3ß2 Nicotinic Acetylcholine Receptors. J. Med. Chem. 2019, 62, 6262-6275. [CrossRef]

60. Hone, A.J.; Scadden, M.; Gajewiak, J.; Christensen, S.; Lindstrom, J.; McIntosh, J.M. $\alpha$-Conotoxin PeIA[S9H,V10A,E14N] Potently and Selectively Blocks A6 $\beta 2 \beta 3$ versus A6 $\beta 4$ Nicotinic Acetylcholine Receptors. Mol. Pharmacol. 2012, 82, 972-982. [CrossRef]

61. Luo, S.; Nguyen, T.A.; Cartier, G.E.; Olivera, B.M.; Yoshikami, D.; McIntosh, J.M. Single-Residue Alteration in $\alpha$-Conotoxin PnIA Switches Its NAChR Subtype Selectivity. Biochemistry 1999, 38, 14542-14548. [CrossRef] [PubMed]

62. Hogg, R.C.; Hopping, G.; Alewood, P.F.; Adams, D.J.; Bertrand, D. Alpha-Conotoxins PnIA and [A10L]PnIA Stabilize Different States of the Alpha7-L247T Nicotinic Acetylcholine Receptor. J. Biol. Chem. 2003, 278, 26908-26914. [CrossRef]

63. Kompella, S.N.; Hung, A.; Clark, R.J.; Marí, F.; Adams, D.J. Alanine Scan of $\alpha$-Conotoxin RegIIA Reveals a Selective A3 $\beta 4$ Nicotinic Acetylcholine Receptor Antagonist. J. Biol. Chem. 2015, 290, 1039-1048. [CrossRef]

64. Luo, S.; Zhangsun, D.; Zhu, X.; Wu, Y.; Hu, Y.; Christensen, S.; Harvey, P.J.; Akcan, M.; Craik, D.J.; McIntosh, J.M. Characterization of a Novel $\alpha$-Conotoxin TxID from Conus Textile That Potently Blocks Rat A3 $\beta 4$ Nicotinic Acetylcholine Receptors. J. Med. Chem. 2013, 56, 9655-9663. [CrossRef]

65. Jin, A.-H.; Vetter, I.; Dutertre, S.; Abraham, N.; Emidio, N.B.; Inserra, M.; Murali, S.S.; Christie, M.J.; Alewood, P.F.; Lewis, R.J. $\mathrm{MrIC}$, a Novel $\alpha$-Conotoxin Agonist in the Presence of PNU at Endogenous A7 Nicotinic Acetylcholine Receptors. Biochemistry 2014, 53, 1-3. [CrossRef]

66. Halai, R.; Clark, R.J.; Nevin, S.T.; Jensen, J.E.; Adams, D.J.; Craik, D.J. Scanning Mutagenesis of Alpha-Conotoxin Vc1.1 Reveals Residues Crucial for Activity at the Alpha9alpha10 Nicotinic Acetylcholine Receptor. J. Biol. Chem. 2009, 284, $20275-20284$. [CrossRef]

67. Dutton, J.L.; Craik, D.J. Alpha-Conotoxins: Nicotinic Acetylcholine Receptor Antagonists as Pharmacological Tools and Potential Drug Leads. Curr. Med. Chem. 2001, 8, 327-344. [CrossRef]

68. Halai, R.; Craik, D.J. Conotoxins: Natural Product Drug Leads. Nat. Prod. Rep. 2009, 26, 526-536. [CrossRef] [PubMed]

69. Li, X.; Tae, H.-S.; Chu, Y.; Jiang, T.; Adams, D.J.; Yu, R. Medicinal Chemistry, Pharmacology, and Therapeutic Potential of $\alpha$-Conotoxins Antagonizing the A9 $\alpha 10$ Nicotinic Acetylcholine Receptor. Pharmacol. Ther. 2020, 222, 107792. [CrossRef]

70. Di Cesare Mannelli, L.; Cinci, L.; Micheli, L.; Zanardelli, M.; Pacini, A.; McIntosh, J.M.; Ghelardini, C. $\alpha$-Conotoxin RgIA Protects against the Development of Nerve Injury-Induced Chronic Pain and Prevents Both Neuronal and Glial Derangement. Pain 2014, 155, 1986-1995. [CrossRef]

71. Hone, A.J.; Servent, D.; McIntosh, J.M. A9-Containing Nicotinic Acetylcholine Receptors and the Modulation of Pain. Br. J. Pharmacol. 2018, 175, 1915-1927. [CrossRef]

72. Mohammadi, S.; Christie, M.J. A9-Nicotinic Acetylcholine Receptors Contribute to the Maintenance of Chronic Mechanical Hyperalgesia, but Not Thermal or Mechanical Allodynia. Mol. Pain 2014, 10, 1744-8069. [CrossRef]

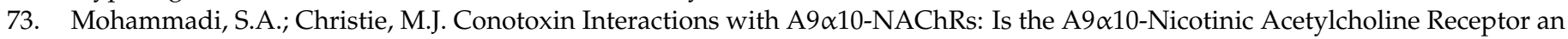
Important Therapeutic Target for Pain Management? Toxins 2015, 7, 3916-3932. [CrossRef] [PubMed]

74. Vincler, M.; McIntosh, J.M. Targeting the A9 10 Nicotinic Acetylcholine Receptor to Treat Severe Pain. Expert Opin. Ther. Targets 2007, 11, 891-897. [CrossRef] [PubMed]

75. Satkunanathan, N.; Livett, B.; Gayler, K.; Sandall, D.; Down, J.; Khalil, Z. Alpha-Conotoxin Vc1.1 Alleviates Neuropathic Pain and Accelerates Functional Recovery of Injured Neurones. Brain Res. 2005, 1059, 149-158. [CrossRef]

76. Romero, H.K.; Christensen, S.B.; Di Cesare Mannelli, L.; Gajewiak, J.; Ramachandra, R.; Elmslie, K.S.; Vetter, D.E.; Ghelardini, C.; Iadonato, S.P.; Mercado, J.L.; et al. Inhibition of A9 10 Nicotinic Acetylcholine Receptors Prevents Chemotherapy-Induced Neuropathic Pain. Proc. Natl. Acad. Sci. USA 2017, 114, E1825-E1832. [CrossRef] 
77. Christensen, S.B.; Hone, A.J.; Roux, I.; Kniazeff, J.; Pin, J.-P.; Upert, G.; Servent, D.; Glowatzki, E.; McIntosh, J.M. RgIA4 Potently Blocks Mouse A9 $\alpha 10$ NAChRs and Provides Long Lasting Protection against Oxaliplatin-Induced Cold Allodynia. Front. Cell. Neurosci. 2017, 11, 219. [CrossRef] [PubMed]

78. AlSharari, S.D.; Toma, W.; Mahmood, H.M.; Michael McIntosh, J.; Imad Damaj, M. The A9 $\alpha 10$ Nicotinic Acetylcholine Receptors Antagonist $\alpha$-Conotoxin RgIA Reverses Colitis Signs in Murine Dextran Sodium Sulfate Model. Eur. J. Pharmacol. 2020, 883, 173320. [CrossRef]

79. Qian, J.; Liu, Y.-Q.; Sun, Z.-H.; Zhangsun, D.-T.; Luo, S.-L. Identification of Nicotinic Acetylcholine Receptor Subunits in Different Lung Cancer Cell Lines and the Inhibitory Effect of Alpha-Conotoxin TxID on Lung Cancer Cell Growth. Eur. J. Pharmacol. 2019, 865, 172674. [CrossRef] [PubMed]

80. Bertrand, D.; Terry, A.V.J. The Wonderland of Neuronal Nicotinic Acetylcholine Receptors. Biochem. Pharmacol. 2018, 151, 214-225. [CrossRef]

81. Ellison, M.; Gao, F.; Wang, H.-L.; Sine, S.M.; McIntosh, J.M.; Olivera, B.M. $\alpha$-Conotoxins ImI and ImII Target Distinct Regions of the Human A7 Nicotinic Acetylcholine Receptor and Distinguish Human Nicotinic Receptor Subtypes. Biochemistry 2004, 43, 16019-16026. [CrossRef] [PubMed]

82. Ellison, M.; Haberlandt, C.; Gomez-Casati, M.E.; Watkins, M.; Elgoyhen, A.B.; McIntosh, J.M.; Olivera, B.M. $\alpha$-RgIA: A Novel Conotoxin That Specifically and Potently Blocks the A9 $\alpha 10$ NAChR. Biochemistry 2006, 45, 1511-1517. [CrossRef]

83. López-Vera, E.; Jacobsen, R.B.; Ellison, M.; Olivera, B.M.; Teichert, R.W. A Novel Alpha Conotoxin (Alpha-PIB) Isolated from C. Purpurascens Is Selective for Skeletal Muscle Nicotinic Acetylcholine Receptors. Toxicon 2007, 49, 1193-1199. [CrossRef]

84. Luo, S.; Kulak, J.M.; Cartier, G.E.; Jacobsen, R.B.; Yoshikami, D.; Olivera, B.M.; McIntosh, J.M. Alpha-Conotoxin AuIB Selectively Blocks Alpha3 Beta4 Nicotinic Acetylcholine Receptors and Nicotine-Evoked Norepinephrine Release. J. Neurosci. 1998, 18, 8571-8579. [CrossRef]

85. Nicke, A.; Samochocki, M.; Loughnan, M.L.; Bansal, P.S.; Maelicke, A.; Lewis, R.J. $\alpha$-Conotoxins EpI and AuIB Switch Subtype Selectivity and Activity in Native versus Recombinant Nicotinic Acetylcholine Receptors. FEBS Lett. 2003, 554, $219-223$. [CrossRef]

86. Martinez, J.S.; Olivera, B.M.; Gray, W.R.; Craig, A.G.; Groebe, D.R.; Abramson, S.N.; McIntosh, J.M. Alpha.-Conotoxin EI, A New Nicotinic Acetylcholine Receptor Antagonist with Novel Selectivity. Biochemistry 1995, 34, 14519-14526. [CrossRef] [PubMed]

87. McIntosh, J.M.; Dowell, C.; Watkins, M.; Garrett, J.E.; Yoshikami, D.; Olivera, B.M. $\alpha$-Conotoxin GIC from Conus Geographus, a Novel Peptide Antagonist of Nicotinic Acetylcholine Receptors. J. Biol. Chem. 2002, 277, 33610-33615. [CrossRef]

88. Nicke, A.; Loughnan, M.L.; Millard, E.L.; Alewood, P.F.; Adams, D.J.; Daly, N.L.; Craik, D.J.; Lewis, R.J. Isolation, Structure, and Activity of GID, a Novel Alpha 4/7-Conotoxin with an Extended N-Terminal Sequence. J. Biol. Chem. 2003, 278, 3137-3144. [CrossRef] [PubMed]

89. Millard, E.L.; Nevin, S.T.; Loughnan, M.L.; Nicke, A.; Clark, R.J.; Alewood, P.F.; Lewis, R.J.; Adams, D.J.; Craik, D.J.; Daly, N.L. Inhibition of Neuronal Nicotinic Acetylcholine Receptor Subtypes by Alpha-Conotoxin GID and Analogues. J. Biol. Chem. 2009, 284, 4944-4951. [CrossRef]

90. Luo, S.; Akondi, K.B.; Zhangsun, D.; Wu, Y.; Zhu, X.; Hu, Y.; Christensen, S.; Dowell, C.; Daly, N.L.; Craik, D.J.; et al. Atypical $\alpha$-Conotoxin LtIA from Conus Litteratus Targets a Novel Microsite of the A3ß2 Nicotinic Receptor. J. Biol. Chem. 2010, 285, 12355-12366. [CrossRef]

91. Cartier, G.E.; Yoshikami, D.; Gray, W.R.; Luo, S.; Olivera, B.M.; McIntosh, J.M. A New $\alpha$-Conotoxin Which Targets A3 $\beta 2$ Nicotinic Acetylcholine Receptors. J. Biol. Chem. 1996, 271, 7522-7528. [CrossRef] [PubMed]

92. McIntosh, J.M.; Plazas, P.V.; Watkins, M.; Gomez-Casati, M.E.; Olivera, B.M.; Elgoyhen, A.B. A Novel Alpha-Conotoxin, PeIA, Cloned from Conus Pergrandis, Discriminates between Rat Alpha9alpha10 and Alpha7 Nicotinic Cholinergic Receptors. J. Biol. Chem. 2005, 280, 30107-30112. [CrossRef]

93. Franco, A.; Kompella, S.N.; Akondi, K.B.; Melaun, C.; Daly, N.L.; Luetje, C.W.; Alewood, P.F.; Craik, D.J.; Adams, D.J.; Marí, F. RegIIA: An A4/7-Conotoxin from the Venom of Conus Regius That Potently Blocks A3ß4 NAChRs. Biochem. Pharmacol. 2012, 83, 419-426. [CrossRef] [PubMed]

94. Clark, R.J.; Fischer, H.; Nevin, S.T.; Adams, D.J.; Craik, D.J. The Synthesis, Structural Characterization, and Receptor Specificity of the Alpha-Conotoxin Vc1.1. J. Biol. Chem. 2006, 281, 23254-23263. [CrossRef] [PubMed]

95. Kessler, P.; Marchot, P.; Silva, M.; Servent, D. The Three-Finger Toxin Fold: A Multifunctional Structural Scaffold Able to Modulate Cholinergic Functions. J. Neurochem. 2017, 142, 7-18. [CrossRef]

96. Tsetlin, V.I.; Kasheverov, I.E.; Utkin, Y.N. Three-Finger Proteins from Snakes and Humans Acting on Nicotinic Receptors: Old and New. J. Neurochem. 2020. [CrossRef]

97. Nirthanan, S.; Gopalakrishnakone, P.; Gwee, M.C.E.; Khoo, H.E.; Kini, R.M. Non-Conventional Toxins from Elapid Venoms. Toxicon 2003, 41, 397-407. [CrossRef]

98. Utkin, Y.N.; Kukhtina, V.V.; Kryukova, E.V.; Chiodini, F.; Bertrand, D.; Methfessel, C.; Tsetlin, V.I. “Weak Toxin” from Naja Kaouthia Is a Nontoxic Antagonist of A7 and Muscle-Type Nicotinic Acetylcholine Receptors. J. Biol. Chem. 2001, 276, 15810-15815. [CrossRef]

99. Nirthanan, S.; Charpantier, E.; Gopalakrishnakone, P.; Gwee, M.C.E.; Khoo, H.-E.; Cheah, L.-S.; Bertrand, D.; Kini, R.M. Candoxin, a Novel Toxin from Bungarus Candidus, Is a Reversible Antagonist of Muscle $(\mathrm{A} \beta \gamma \delta$ ) but a Poorly Reversible Antagonist of Neuronal A7 Nicotinic Acetylcholine Receptors. J. Biol. Chem. 2002, 277, 17811-17820. [CrossRef] 
100. Osipov, A.V.; Kasheverov, I.E.; Makarova, Y.V.; Starkov, V.G.; Vorontsova, O.V.; Ziganshin, R.K.; Andreeva, T.V.; Serebryakova, M.V.; Benoit, A.; Hogg, R.C.; et al. Naturally Occurring Disulfide-Bound Dimers of Three-Fingered Toxins. J. Biol. Chem. 2008, 283, 14571-14580. [CrossRef] [PubMed]

101. Osipov, A.V.; Rucktooa, P.; Kasheverov, I.E.; Filkin, S.Y.; Starkov, V.G.; Andreeva, T.V.; Sixma, T.K.; Bertrand, D.; Utkin, Y.N.; Tsetlin, V.I. Dimeric $\alpha$-Cobratoxin X-ray structure: Localization of intermolecular disulfides and possible mode of binding to nicotinic acetylcholine receptors. J. Biol. Chem. 2012, 287, 6725-6734. [CrossRef] [PubMed]

102. Foo, C.S.; Jobichen, C.; Hassan-Puttaswamy, V.; Dekan, Z.; Tae, H.-S.; Bertrand, D.; Adams, D.J.; Alewood, P.F.; Sivaraman, J.; Nirthanan, S.; et al. Fulditoxin, Representing a New Class of Dimeric Snake Toxins, Defines Novel Pharmacology at Nicotinic ACh Receptors. Br. J. Pharmacol. 2020, 177, 1822-1840. [CrossRef] [PubMed]

103. Pawlak, J.; Mackessy, S.P.; Sixberry, N.M.; Stura, E.A.; Le Du, M.H.; Ménez, R.; Foo, C.S.; Ménez, A.; Nirthanan, S.; Kini, R.M. Irditoxin, a Novel Covalently Linked Heterodimeric Three-Finger Toxin with High Taxon-Specific Neurotoxicity. FASEB J. 2009, 23, 534-545. [CrossRef] [PubMed]

104. Nirthanan, S. Snake Three-Finger $\alpha$-Neurotoxins and Nicotinic Acetylcholine Receptors: Molecules, Mechanisms and Medicine. Biochem. Pharmacol. 2020, 181, 114168. [CrossRef] [PubMed]

105. Chang, C.C. Looking Back on the Discovery of $\alpha$-Bungarotoxin. J. Biomed. Sci. 1999, 6, 368-375. [CrossRef]

106. Changeux, J.P.; Kasai, M.; Lee, C.Y. Use of a Snake Venom Toxin to Characterize the Cholinergic Receptor Protein. Proc. Natl. Acad. Sci. USA 1970, 67, 1241-1247. [CrossRef]

107. Wang, G.K.; Schmidt, J. Primary Structure and Binding Properties of Iodinated Derivatives of Alpha-Bungarotoxin. J. Biol. Chem. 1980, 255, 11156-11162. [CrossRef]

108. Servent, D.; Mourier, G.; Antil, S.; Ménez, A. How Do Snake Curaremimetic Toxins Discriminate between Nicotinic Acetylcholine Receptor Subtypes. Toxicol. Lett. 1998, 102-103, 199-203. [CrossRef]

109. Moise, L.; Piserchio, A.; Basus, V.J.; Hawrot, E. NMR Structural Analysis of $\alpha$-Bungarotoxin and Its Complex with the Principal $\alpha$-Neurotoxin-Binding Sequence on the A7 Subunit of a Neuronal Nicotinic Acetylcholine Receptor. J. Biol. Chem. 2002, 277, 12406-12417. [CrossRef]

110. Dellisanti, C.D.; Yao, Y.; Stroud, J.C.; Wang, Z.-Z.; Chen, L. Crystal Structure of the Extracellular Domain of NAChR A1 Bound to $\alpha$-Bungarotoxin at $1.94 \AA$ Resolution. Nat. Neurosci. 2007, 10, 953-962. [CrossRef]

111. Huang, S.; Li, S.-X.; Bren, N.; Cheng, K.; Gomoto, R.; Chen, L.; Sine, S.M. Complex between $\alpha$-Bungarotoxin and an A7 Nicotinic Receptor Ligand-Binding Domain Chimaera. Biochem. J. 2013, 454, 303-310. [CrossRef] [PubMed]

112. Zouridakis, M.; Giastas, P.; Zarkadas, E.; Chroni-Tzartou, D.; Bregestovski, P.; Tzartos, S.J. Crystal Structures of Free and Antagonist-Bound States of Human A9 Nicotinic Receptor Extracellular Domain. Nat. Struct. Mol. Biol. 2014, 21, 976-980. [CrossRef]

113. Rahman, M.M.; Teng, J.; Worrell, B.T.; Noviello, C.M.; Lee, M.; Karlin, A.; Stowell, M.H.B.; Hibbs, R.E. Structure of the Native Muscle-Type Nicotinic Receptor and Inhibition by Snake Venom Toxins. Neuron 2020, 106, 952-962.e5. [CrossRef]

114. Antil-Delbeke, S.; Gaillard, C.; Tamiya, T.; Corringer, P.-J.; Changeux, J.-P.; Servent, D.; Ménez, A. Molecular Determinants by Which a Long Chain Toxin from Snake Venom Interacts with the Neuronal A7-Nicotinic Acetylcholine Receptor. J. Biol. Chem. 2000, 275, 29594-29601. [CrossRef]

115. Fruchart-Gaillard, C.; Gilquin, B.; Antil-Delbeke, S.; Le Novère, N.; Tamiya, T.; Corringer, P.-J.; Changeux, J.-P.; Ménez, A.; Servent, D. Experimentally Based Model of a Complex between a Snake Toxin and the A7 Nicotinic Receptor. Proc. Natl. Acad. Sci. USA 2002, 99, 3216. [CrossRef]

116. Bourne, Y.; Talley, T.T.; Hansen, S.B.; Taylor, P.; Marchot, P. Crystal Structure of a Cbtx-AChBP Complex Reveals Essential Interactions between Snake $\alpha$-Neurotoxins and Nicotinic Receptors. EMBO J. 2005, 24, 1512-1522. [CrossRef]

117. Utkin, Y.N.; Kuch, U.; Kasheverov, I.E.; Lebedev, D.S.; Cederlund, E.; Molles, B.E.; Polyak, I.; Ivanov, I.A.; Prokopev, N.A.; Ziganshin, R.H.; et al. Novel Long-Chain Neurotoxins from Bungarus Candidus Distinguish the Two Binding Sites in Muscle-Type Nicotinic Acetylcholine Receptors. Biochem. J. 2019, 476, 1285-1302. [CrossRef]

118. Chandna, R.; Tae, H.-S.; Seymour, V.A.L.; Chathrath, S.; Adams, D.J.; Kini, R.M. Drysdalin, an Antagonist of Nicotinic Acetylcholine Receptors Highlights the Importance of Functional Rather than Structural Conservation of Amino Acid Residues. FASEB BioAdv. 2019, 1, 115-131. [CrossRef]

119. Servent, D.; Winckler-Dietrich, V.; Hu, H.-Y.; Kessler, P.; Drevet, P.; Bertrand, D.; Ménez, A. Only Snake Curaremimetic Toxins with a Fifth Disulfide Bond Have High Affinity for the Neuronal A7 Nicotinic Receptor. J. Biol. Chem. 1997, 272, 24279-24286. [CrossRef] [PubMed]

120. Trémeau, O.; Lemaire, C.; Drevet, P.; Pinkasfeld, S.; Ducancel, F.; Boulain, J.-C.; Ménez, A. Genetic Engineering of Snake Toxins: The functional site of Erabutoxin a, as delineated by site-directed mutagenesis, includes variant residues. J. Biol. Chem. 1995, 270, 9362-9369. [CrossRef] [PubMed]

121. Teixeira-Clerc, F.; Ménez, A.; Kessler, P. How Do Short Neurotoxins Bind to a Muscular-Type Nicotinic Acetylcholine Receptor? J. Biol. Chem. 2002, 277, 25741-25747. [CrossRef] [PubMed]

122. Ackermann, E.J.; Taylor, P. Nonidentity of the $\alpha$-Neurotoxin Binding Sites on the Nicotinic Acetylcholine Receptor Revealed by Modification in $\alpha$-Neurotoxin and Receptor Structures. Biochemistry 1997, 36, 12836-12844. [CrossRef] [PubMed]

123. Osaka, H.; Malany, S.; Kanter, J.R.; Sine, S.M.; Taylor, P. Subunit Interface Selectivity of the Alpha-Neurotoxins for the Nicotinic Acetylcholine Receptor. J. Biol. Chem. 1999, 274, 9581-9586. [CrossRef] 
124. Roy, A.; Zhou, X.; Chong, M.Z.; D’hoedt, D.; Foo, C.S.; Rajagopalan, N.; Nirthanan, S.; Bertrand, D.; Sivaraman, J.; Kini, R.M. Structural and Functional Characterization of a Novel Homodimeric Three-Finger Neurotoxin from the Venom of Ophiophagus Hannah (King Cobra). J. Biol. Chem. 2010, 285, 8302-8315. [CrossRef] [PubMed]

125. Betzel, C.; Lange, G.; Pal, G.P.; Wilson, K.S.; Maelicke, A.; Saenger, W. The Refined Crystal Structure of Alpha-Cobratoxin from Naja Naja Siamensis at 2.4-A Resolution. J. Biol. Chem. 1991, 266, 21530-21536. [CrossRef]

126. Chatrath, S.T.; Chapeaurouge, A.; Lin, Q.; Lim, T.K.; Dunstan, N.; Mirtschin, P.; Kumar, P.P.; Kini, R.M. Identification of Novel Proteins from the Venom of a Cryptic Snake Drysdalia Coronoides by a Combined Transcriptomics and Proteomics Approach. J. Proteome Res. 2011, 10, 739-750. [CrossRef] [PubMed]

127. Pillet, L.; Trémeau, O.; Ducancel, F.; Drevet, P.; Zinn-Justin, S.; Pinkasfeld, S.; Boulain, J.C.; Ménez, A. Genetic Engineering of Snake Toxins. Role of Invariant Residues in the Structural and Functional Properties of a Curaremimetic Toxin, as Probed by Site-Directed Mutagenesis. J. Biol. Chem. 1993, 268, 909-916. [CrossRef]

128. Dewan, J.C.; Grant, G.A.; Sacchettini, J.C. Crystal Structure of Kappa-Bungarotoxin at 2.3-A Resolution. Biochemistry 1994, 33, 13147-13154. [CrossRef]

129. Chiappinelli, V.A.; Weaver, W.R.; McLane, K.E.; Conti-Fine, B.M.; Fiordalisi, J.J.; Grant, G.A. Binding of Native k-Neurotoxins and Site-Directed Mutants to Nicotinic Acetylcholine Receptors. Toxicon 1996, 34, 1243-1256. [CrossRef]

130. Mordvintsev, D.Y.; Polyak, Y.L.; Rodionov, D.I.; Jakubik, J.; Dolezal, V.; Karlsson, E.; Tsetlin, V.I.; Utkin, Y.N. Weak Toxin WTX from Naja Kaouthia Cobra Venom Interacts with Both Nicotinic and Muscarinic Acetylcholine Receptors. FEBS J. 2009, 276, 5065-5075. [CrossRef]

131. Lyukmanova, E.N.; Shulepko, M.A.; Shenkarev, Z.O.; Kasheverov, I.E.; Chugunov, A.O.; Kulbatskii, D.S.; Myshkin, M.Y.; Utkin, Y.N.; Efremov, R.G.; Tsetlin, V.I.; et al. Central Loop of Non-Conventional Toxin WTX from Naja Kaouthia Is Important for Interaction with Nicotinic Acetylcholine Receptors. Toxicon 2016, 119, 274-279. [CrossRef] [PubMed]

132. Pawlak, J.; Mackessy, S.P.; Fry, B.G.; Bhatia, M.; Mourier, G.; Fruchart-Gaillard, C.; Servent, D.; Ménez, R.; Stura, E.; Ménez, A.; et al. Denmotoxin, a Three-Finger Toxin from the Colubrid Snake Boiga Dendrophila (Mangrove Catsnake) with Bird-Specific Activity. J. Biol. Chem. 2006, 281, 29030-29041. [CrossRef] [PubMed]

133. Kim, H.S.; Tamiya, N. Amino Acid Sequences of Two Novel Long-Chain Neurotoxins from the Venom of the Sea Snake Laticauda Colubrina. Biochem. J. 1982, 207, 215-223. [CrossRef] [PubMed]

134. Chang, L.-S.; Liou, J.-C.; Lin, S.-R.; Huang, H.-B. Purification and Characterization of a Neurotoxin from the Venom of Ophiophagus Hannah (King Cobra). Biochem. Biophys. Res. Commun. 2002, 294, 574-578. [CrossRef]

135. Hassan-Puttaswamy, V.; Adams, D.J.; Kini, R.M. A Distinct Functional Site in $\Omega$-Neurotoxins: Novel Antagonists of Nicotinic Acetylcholine Receptors from Snake Venom. ACS Chem. Biol. 2015, 10, 2805-2815. [CrossRef]

136. Molles, B.E.; Rezai, P.; Kline, E.F.; McArdle, J.J.; Sine, S.M.; Taylor, P. Identification of Residues at the $\alpha$ and $\varepsilon$ Subunit Interfaces Mediating Species Selectivity of Waglerin-1 for Nicotinic Acetylcholine Receptors. J. Biol. Chem. 2002, 277, 5433-5440. [CrossRef]

137. Ye, J.-H.; McArdle, J.J. Waglerin-1 Modulates $\gamma$-Aminobutyric Acid Activated Current of Murine Hypothalamic Neurons. J. Pharmacol. Exp. Ther. 1997, 282, 74.

138. Sellin, L.C.; Mattila, K.; Annila, A.; Schmidt, J.J.; McArdle, J.J.; Hyvönen, M.; Rantala, T.T.; Kivistö, T. Conformational Analysis of a Toxic Peptide from Trimeresurus Wagleri Which Blocks the Nicotinic Acetylcholine Receptor. Biophys. J. 1996, 70, 3-13. [CrossRef]

139. Lyukmanova, E.N.; Shenkarev, Z.O.; Shulepko, M.A.; Paramonov, A.S.; Chugunov, A.O.; Janickova, H.; Dolejsi, E.; Dolezal, V.; Utkin, Y.N.; Tsetlin, V.I.; et al. Structural Insight into Specificity of Interactions between Nonconventional Three-Finger Weak Toxin from Naja Kaouthia (WTX) and Muscarinic Acetylcholine Receptors. J. Biol. Chem. 2015, 290, 23616-23630. [CrossRef]

140. McArdle, J.J.; Lentz, T.L.; Witzemann, V.; Schwarz, H.; Weinstein, S.A.; Schmidt, J.J. Waglerin-1 Selectively Blocks the Epsilon Form of the Muscle Nicotinic Acetylcholine Receptor. J. Pharmacol. Exp. Ther. 1999, 289, 543.

141. Liang, S.; Zhang, D.; Pan, X.; Chen, Q.; Zhou, P. Properties and Amino Acid Sequence of Huwentoxin-I, a Neurotoxin Purified from the Venom of the Chinese Bird Spider Selenocosmia Huwena. Toxicon 1993, 31, 969-978. [CrossRef]

142. Zhou, P.; Xie, X.; Li, M.; Yang, D.; Xie, Z.-P.; Zong, X.; Liang, S. Blockade of Neuromuscular Transmission by Huwentoxin-I, Purified from the Venom of the Chinese Bird Spider Selenocosmia Huwena. Toxicon 1997, 35, 39-45. [CrossRef]

143. Liang, S.-P.; Chen, X.-D.; Shu, Q.; Zhang, Y.; Peng, K. The Presynaptic Activity of Huwentoxin-I, a Neurotoxin from the Venom of the Chinese Bird Spider Selenocosmia Huwena. Toxicon 2000, 38, 1237-1246. [CrossRef]

144. Peng, K.; Chen, X.D.; Liang, S.P. The Effect of Huwentoxin-I on Ca(2+) Channels in Differentiated NG108-15 Cells, a Patch-Clamp Study. Toxicon 2001, 39, 491-498. [CrossRef]

145. Wang, M.; Guan, X.; Liang, S. The Cross Channel Activities of Spider Neurotoxin Huwentoxin-I on Rat Dorsal Root Ganglion Neurons. Biochem. Biophys. Res. Commun. 2007, 357, 579-583. [CrossRef] [PubMed]

146. Granja, R.; Fernández-Fernández, J.; Izaguirre, V.; González-García, C.; Ceña, V. w-Agatoxin IVA Blocks Nicotinic Receptor Channels in Bovine Chromaffin Cells. FEBS Lett. 1995, 362, 15-18. [CrossRef]

147. Wang, J.; Irnaten, M.; Mendelowitz, D. Agatoxin-IVA-Sensitive Calcium Channels Mediate the Presynaptic and Postsynaptic Nicotinic Activation of Cardiac Vagal Neurons. J. Neurophysiol. 2001, 85, 164-168. [CrossRef]

148. Adams, M.E. Agatoxins: Ion Channel Specific Toxins from the American Funnel Web Spider, Agelenopsis Aperta. Toxicon 2004, 43, 509-525. [CrossRef] 
149. Windley, M.J.; Vetter, I.; Lewis, R.J.; Nicholson, G.M. Lethal Effects of an Insecticidal Spider Venom Peptide Involve Positive Allosteric Modulation of Insect Nicotinic Acetylcholine Receptors. Neuropharmacology 2017, 127, 224-242. [CrossRef]

150. Bergeron, Z.L.; Bingham, J.-P. Scorpion Toxins Specific for Potassium (K+) Channels: A Historical Overview of Peptide Bioengineering. Toxins 2012, 4, 1082-1119. [CrossRef]

151. Gurevitz, M.; Gordon, D.; Barzilai, M.G.; Kahn, R.; Cohen, L.; Moran, Y.; Zilberberg, N.; Froy, O.; Altman-Gueta, H.; Turkov, M.; et al. Molecular Description of Scorpion Toxin Interaction with Voltage-Gated Sodium Channels. In Scorpion Venoms; Gopalakrishnakone, P., Possani, L.D., Schwartz, E., Rodríguez de la Vega, R.C., Eds.; Springer: Dordrecht, The Netherlands, 2015; pp. 471-491. ISBN 978-94-007-6404-0.

152. Quintero-Hernández, V.; Jiménez-Vargas, J.M.; Gurrola, G.B.; Valdivia, H.H.; Possani, L.D. Scorpion Venom Components That Affect Ion-Channels Function. Toxicon 2013, 76, 328-342. [CrossRef] [PubMed]

153. Kasheverov, I.E.; Oparin, P.B.; Zhmak, M.N.; Egorova, N.S.; Ivanov, I.A.; Gigolaev, A.M.; Nekrasova, O.V.; Serebryakova, M.V.; Kudryavtsev, D.S.; Prokopev, N.A.; et al. Scorpion Toxins Interact with Nicotinic Acetylcholine Receptors. FEBS Lett. 2019, 593, 2779-2789. [CrossRef] [PubMed]

154. Mouhat, S.; Visan, V.; Ananthakrishnan, S.; Wulff, H.; Andreotti, N.; Grissmer, S.; Darbon, H.; De Waard, M.; Sabatier, J.-M. K+ Channel Types Targeted by Synthetic OSK1, a Toxin from Orthochirus Scrobiculosus Scorpion Venom. Biochem. J. 2004, 385, 95-104. [CrossRef] [PubMed] 